\title{
EMPTY VOTING E HIDDEN (MORPHABLE) OWNERSHIP: OS NOVOS MECANISMOS DE DISSOCIAÇÃO DOS DIREITOS PATRIMONIAIS E POLÍTICOS DOS ACIONISTAS
}

\author{
EMPTY VOTING AND HIDDEN (MORPHABLE) OWNERSHIP: THE NEW MECHANISMS OF \\ DECOUPLING OF SHAREHOLDERS' ECONOMIC AND POLITICAL RIGHTS
}

\section{Lucas Carneiro Gorgulho Mendes Barros*}

\begin{abstract}
"Lo mejor y mas gracioso de todo es, que sin riesgo podeis ser rico, y sin exponer el caudal à tempestades, correspondientes, desembolços, almahazenes, portes, caxeros, quiebras, y otros accidentes impensados, estais à pique de alcançar la opulencia, mudando solo el nombre en los desaciertos: [...] basta al Accionista que reconoce que está mal, mudar el nombre para librarse de todos los peligros que lo amenaçan y de todos los sustos que lo inquietan"

(VEGA, Joseph de la. Confusion de confusiones: dialogos curiosos entre un philosofo agudo, un mercader discreto, y un accionista erudito descriviendo el negocio de las acciones, su origen, su ethimologia, su realidade, su juego, y su enredo. Amsterdam. 1688, p. 64)
\end{abstract}

Resumo:

Este artigo tem por objetivo sistematizar os novos mecanismos de negociação de votos, seu conceito, contexto e suas principais figuras, i.e., o voto vazio (empty voting) e a propriedade oculta (conversível) (hidden (morphable) ownership). $\mathrm{O}$ artigo busca, igualmente, apontar os possíveis impactos dos fenômenos na estrutura interna das companhias e os desafios colocados na perspectiva de Direito Societário.

Palavras-chave: Voto vazio. Propriedade oculta. Propriedade oculta (conversível). Empty voting. Hidden ownership. Hidden (morphable) ownership. Direitos do acionista. Sociedades anônimas.

\begin{abstract}
:
This paper aims to systematize the new mechanisms of vote buying, their concept, context and main phenomena, i.e., empty voting and hidden (morphable) ownership. It aims also to indicate potential impacts of the phenomena in the internal structure of corporations and the challenges posed in the perspective of Corporate Law.
\end{abstract}

Keywords: Empty voting. Hidden ownership. Hidden (morphable) ownership. The new vote buying. Shareholder rights. Corporations.

* Graduado e mestrando em Direito Societário pela Universidade de São Paulo. Advogado em São Paulo. 
1. Introdução

A realidade das sociedades por ações passou por inúmeras transformações em suas dinâmicas interna (interna corporis) e externa (no mercado), acompanhadas dos reflexos correspondentes no arcabouço jurídico a elas aplicável. ${ }^{1}$ Em ao menos três momentos dessa evolução, após a consolidação das sociedades por ações no século XVII, ${ }^{2}$ houve inflexões relevantes na dinâmica das companhias, que propiciaram a dissociação entre dois elementos originalmente inseparáveis.

A primeira dessas transformações pode ser observada no destacamento entre a posição do acionista, titular de quotas ideais das sociedades, e a figura do consumidor dos bens e serviços por elas oferecidos, ocorrido no século XIX. ${ }^{3}$

A segunda dessas transformações na dinâmica das sociedades por ações corresponde ao movimento de separação entre propriedade e controle, muito discutido a partir de meados do século $\mathrm{XX}^{4}$ - ainda que o fenômeno possa também ser reconhecido desde primórdios do desenvolvimento das sociedades por ações, na separação entre o controle efetivo sobre as atividades desenvolvidas pelas sociedades e os riscos econômicos do negócio. ${ }^{5}$

O século XXI, por sua vez, inicia em meio a uma nova revolução na dinâmica das sociedades anônimas - em grande medida invisível e imperceptível -, relacionada ao progressivo desenvolvimento dos mercados financeiro e de capitais, acompanhado do expressivo crescimento do mercado de derivativos e outros instrumentos financeiros. ${ }^{6}$ Trata-se da separação entre os direitos políticos, especialmente o direito de voto, e o conteúdo econômico relacionado à titularidade das ações, ou seja, sua propriedade

1 Sobre o caráter indutivo do direito comercial, cf. Irti (2004). No Brasil, sobre os múltiplos aspectos do direito comercial, dentre eles o de "dimensão da realidade, na qual se imiscuem fatos, regras exógenas e endógenas, o comportamento dos agentes econômicos e outros aspectos ligados a essa mesma realidade", cf. Forgioni (2009, p. 16 et seq.). Para histórico aprofundado do direito comercial, cf. Goldschmidt (1891).

2 O período histórico inicial das sociedades anônimas, no contexto das Grandes Navegações, é bem reportado por Dari-Mattiacci (2017).

3 Sobre a separação entre "propriedade" e "consumo", vide Hansmann e Pargendler (2014). Os autores destacam que a dissociação entre "propriedade" e "consumo" precedeu a separação entre "propriedade" e "controle", e, embora menos estudada, caracteriza-se igualmente como uma inflexão história das companhias, da mesma forma que explica a difusão de estruturas distintas do princípio de one share, one vote em sociedades no século XIX. Sobre o modelo de sobreposição econômica de propriedade e consumo, vide também Hansmann (1996).

4 A separação entre propriedade e controle foi muito estudada e discutida a partir do estudo seminal de Berle Jr. e Means (1936).

5 Cf. Mignoli (2007, p. 214 et seq.).

6 Sobre os derivativos e a sua relação com o direito societário, cf., i.a., Partnoy (2000); Kniehase (2005) e Hu (1996, p. 39 et seq.). 
econômica, sem alteração na titularidade formal dos direitos patrimoniais, perante a companhia.

Esse fenômeno de separação, ou desacoplamento (decoupling, no original), foi primeiramente sistematizado por Hu e Black, ${ }^{7}$ a partir do estudo de casos observados nos mercados de diversas jurisdições. Trata-se dos novos mecanismos de negociação de votos (the new vote buying, no original), cujas duas principais figuras são: $(i)$ o voto vazio (empty voting, no original); e (ii) a propriedade oculta (conversível) (hidden (morphable) ownership, no original). ${ }^{8}$

Os novos mecanismos de negociação de votos encontram sua aplicação especialmente na dinâmica das companhias abertas, ${ }^{9}$ uma vez que os instrumentos para a dissociação dos direitos de sócio aplicados nessas estruturas (derivativos, empréstimo de ações, opções de compra e venda, etc.) são bastante comuns em operações realizadas em mercado e, portanto, encontram seu locus natural nas sociedades por ações cujos valores mobiliários são admitidos à negociação em mercados regulados. ${ }^{10}$

O fenômeno apresenta especial relevância na perspectiva interna das sociedades anônimas, principalmente quanto aos incentivos existentes sobre os acionistas e aos fundamentos do direito de voto, e responsabilidades correspondentes, afetando premissas basilares do direito societário contemporâneo. O fenômeno tem também relevância na perspectiva externa das sociedades anônimas, em particular nas companhias abertas, já que, embora muitas das operações envolvidas sejam realizadas fora do âmbito societário, do ponto de vista formal, referem-se ao conteúdo econômico decorrente da titularidade de ações e influenciam o comportamento dos acionistas, correspondendo, na essência, a operações sujeitas à incidência de normas regulatórias como de divulgação obrigatória, realização de ofertas públicas obrigatórias, entre outras. ${ }^{11}$

7 Os três primeiros artigos dos autores são: Hu e Black (2006a); Hu e Black (2006b) e Hu e Black (2007). Os autores, posteriormente, estenderam os estudos e produziram a segunda geração de artigos, em conjunto ou individualmente: Hu e Westbrook (2007); Hu e Black (2008a); Hu e Black (2008b) e Hu (2015).

8 Embora se apresentem possíveis traduções neste artigo, os termos que designam os fenômenos estudados [empty voting, hidden (morphable) ownership, entre outros] são usados no original em inglês por se tratar de designações amplamente utilizada pela literatura jurídica internacional que trata do assunto. Quando necessário, e havendo tradução dos termos, o original é apresentado em paralelo, com igual objetivo.

9 As companhias abertas, diante de suas especificidades, estão sujeitas a um regime jurídico, legal e regulatório, especial. Cf., nesse sentido, Bayer (2008). Ver, ainda, sobre as companhias abertas, Jensen (1989). No entanto, as considerações apresentadas podem, em princípio, aplicar-se igualmente às companhias fechadas ou aos demais tipos societários. Reconhecendo que, na prática, os fenômenos não têm aplicação em companhias fechadas, cf. Tautges (2016, p. 36-37).

10 No caso do Brasil, trata-se das companhias registradas perante a Comissão de Valores Mobiliários na condição de emissoras de valores mobiliários, que podem ter suas ações ser negociadas em bolsa de valores e no mercado de balcão, sujeitando-se a registros adicionais.

11 A análise das consequências externas do fenômeno foge ao escopo deste artigo. 
Este artigo tem por objetivo sistematizar os novos mecanismos de negociação de votos, seu conceito, contexto e suas principais figuras, e seus possíveis impactos na perspectiva interna das companhias, de forma a fomentar estudos e discussões posteriores sobre o assunto no Brasil. ${ }^{12}$

\section{O caso Telus}

A Telus Corporation é uma das maiores empresas de telecomunicação do Canadá, localizada em Vancouver, na Colúmbia Britânica. Em 2012, a sociedade tinha seu capital social representado por ações de duas classes: common shares, com direito de voto, e non-voting shares, sem direito de voto. A distinção entre as duas classes de ações correspondia à existência, ou não, de direito de voto; os demais direitos conferidos aos seus titulares eram equivalentes entre si. Ambas as classes de ações eram negociadas em bolsas de valores - o preço das common shares, no entanto, era cerca de 4,5\% superior ao preço das non-voting shares. ${ }^{13}$

Após analisar a possibilidade de extinção da estrutura de duas classes de ações, a partir do final de 2011, a administração da sociedade propôs a unificação das classes de ações, à razão de conversão de 1 non-voting share para 1 common share, sem qualquer prêmio (ainda que as common shares fossem negociadas com prêmio).

A proposta foi submetida à deliberação dos acionistas, na assembleia anual da sociedade, que ocorreria em 9 de maio de 2012. O estudo da proposta contou com a participação de um comitê especial formado por membros independentes (Special Comittee) e de um assessor financeiro independente, Scotia Capital Inc., tendo ambos concluindo que a razão de conversão de 1 para 1 seria adequada na operação.

Após o anúncio da proposta, em 21 de fevereiro de 2012, Mason Capital Mangement LLC, uma gestora de fundos de investimento localizada em Nova York, passou a adquirir ações da Telus (common shares $)^{14}$ e se protegeu do risco relacionado à titularidade das ações, por meio de operações de venda a descoberto de ações de ambas as classes da Telus.

\footnotetext{
12 A literatura jurídica nacional que se dedica ao tema ainda é escassa. Tem-se conhecimento, até o momento, de apenas dois estudos que tratam do assunto: Robert (2015) e Robert (2016).

13 Os fatos que envolvem o caso foram extraídos a partir das reasons for judment de Madam Justice Fitzpatrick (Suprema Corte da Columbia Britânica/Canadá), de 18 de dezembro de 2012, em In re Telus Corporation 2012 BCSC 1919. Foram apresentados apenas os principais fatos, para fins deste estudo. A descrição do caso neste artigo, portanto, não pretende ser extensiva.

14 Embora, neste artigo, para fins de simplificação, sejam feitas referências à Mason Capital, na qualidade de acionista da Telus, ressalta-se que os efetivos acionistas da sociedade eram os diversos fundos de investimento geridos pela Mason Capital.
} 
Em 22 de março do mesmo ano, a Telus divulgou ao mercado comunicado sobre o aumento de participação societária da Mason Capital e a possível intenção da acionista em influenciar o resultado da deliberação sobre a unificação das classes de ações emitidas pela sociedade.

Em 10 de abril de 2012, Mason Capital divulgou ao mercado sua participação societária na Telus, equivalente a pouco menos de $20 \%$ do capital da sociedade. No entanto, considerando as vendas a descoberto por ela realizadas, a acionista estava exposta ao risco econômico de apenas $0,21 \%$ do capital da Telus. Ou seja, embora detivesse a titularidade formal de participação relevante na companhia, os contratos celebrados com terceiros (operações de venda a descoberto de ações) faziam com que a acionista tivesse transferido a exposição econômica na Telus a suas contrapartes.

A partir deste anúncio, Telus e Mason Capital passaram a discutir publicamente a proposta de unificação das ações da sociedade. Mason Capital defendia que a conversão deveria atribuir um prêmio para os titulares das common shares, em lugar da aplicação da razão de conversão de 1 para 1, com fundamento na diferença dos preços de cotação de cada uma das classes de ação. A acionista chegou a circular um pedido público de procuração para os demais acionistas, contra a proposta da administração.

Em 8 de maio de 2012, a administração anunciou que a proposta de unificação das ações da Telus seria retirada da ordem do dia da assembleia geral do dia seguinte e que passaria a analisar alternativas para atingir o mesmo objetivo. A aprovação da proposta de unificação dependeria da aprovação dos acionistas titulares de 2/3 das ações de cada uma das classes, em votações separadas.

Como reação aos objetivos publicamente declarados da administração da Telus, em 2 de agosto de 2012, foi apresentado um pedido de convocação de assembleia geral por solicitação da Mason Capital, ${ }^{15}$ de forma a preestabelecer, no ato constitutivo da Telus, uma razão de conversão das ações, de 1,08 ou 1,0475, garantindo estatutariamente um prêmio para os titulares das common shares. O conselho da Telus se recusou a realizar a convocação.

A Telus, então, convocou uma nova assembleia geral para deliberar pela permuta (exchange, no original), em lugar da conversão, de non-voting shares por common shares, à razão de conversão de 1 para 1, para o dia 17 de outubro de 2012. A aprovação da proposta dependeria do voto favorável de $2 / 3$ das non-voting shares e maioria simples dos titulares das common shares (em vez dos 2/3 necessários em caso da proposta original de conversão).

\footnotetext{
15 O pedido foi apresentado pela CDS Clearing and Depository Services Inc.
} 
Em 30 de agosto de 2012, a assembleia geral de alteração do ato constitutivo da Telus foi convocada a pedido da Mason Capital, para o mesmo dia da assembleia geral convocada pela administração da sociedade. No dia seguinte, Mason Capital reduziu ainda mais sua exposição econômica na Telus, para cerca de $0,021 \%$ do capital social da sociedade.

Mason Capital conseguiu, ainda, o reconhecimento judicial de que seu pedido de convocação fora realizado de forma válida. Na mesma decisão, foi determinado que o fato de Mason Capital ser uma acionista sem a exposição econômica decorrente da titularidade das ações (empty voter, no original) não a impediria de solicitar a convocação de assembleias gerais, na condição de acionista formal, nos termos da lei. ${ }^{16}$

Em razão de decisão judicial, ${ }^{17}$ as assembleias gerais foram realizadas conjuntamente em 17 de outubro de 2012. No conclave, foi aprovada a troca das nonvoting shares por common shares, à razão de conversão de 1 para 1 , conforme proposto pela administração da Telus. Todas as propostas submetidas à apreciação dos acionistas pela Mason Capital foram rejeitadas.

Mason Capital questionou judicialmente a validade da operação. A Suprema Corte da Colúmbia Britânica decidiu que a operação realizada pela Telus foi válida, reconhecendo também que Mason Capital era, com toda a probabilidade (in all likelihood, no original), uma acionista sem a exposição econômica decorrente da titularidade das ações (empty voter, no original). ${ }^{18}$ Em decorrência de sua participação societária formal na Telus, Mason Capital concentrava votos equivalentes a cerca de 1000 vezes o risco econômico correspondente à sua exposição econômica na sociedade, devido às vendas a descoberto realizadas para reduzir sua exposição.

A decisão não foi questionada pela Mason Capital e, assim, a Telus prosseguiu com a unificação das classes das ações representativas de seu capital social.

$\mathrm{O}$ caso da Telus contou com a participação dos professores Hu e Black, os dois sistematizadores dos novos mecanismos de negociação de votos, que defenderam posições antagônicas no caso concreto. Telus apresentou um affidavit preparado pelo professor $\mathrm{Hu},{ }^{19}$ favorável à sua posição. Mason Capital apresentou um artigo encomendado ao professor Black, ${ }^{20}$ em sentido contrário.

16 Decisão da corte de apelação (British Columbia Court of Appeal) de 12 de outubro de 2012, Telus Corporation v. Mason Capital Management LLC, 2012 BCCA 403.

17 Decisão de 15 de outubro de 2012, Mason Capital Management LLC v. TELUS Corporation, 2012 BCSC 1540 .

18 Cf. reasons for judment de Madam Justice Fitzpatrick (Suprema Corte da Columbia Britânica/Canadá), de 18 de dezembro de 2012, em In re Telus Corporation 2012 BCSC 1919.

19 O autor posteriormente tratou do caso em artigo de sua autoria (HU, 2015).

20 Black (2012, p. 3-8). 
De um lado, Hu concluiu que Mason Capital não só era uma acionista que detinha mais votos que sua exposição econômica na Telus (i.e., poderia ser considerada uma empty voter), mas que, na verdade, tinha uma exposição negativa na sociedade. Ou seja, a maximização de seus interesses próprios corresponderia a uma perda de valor para a sociedade e, consequentemente, para os demais acionistas. ${ }^{21}$ De outro lado, Black identificou que Mason Capital tinha interesse econômico sobre o valor dos direitos de voto decorrentes da titularidade das ações, de forma que não poderia ser considerado uma acionista sem interesses na votação (empty voter).

Para chegar à sua conclusão, no entanto, Black usou o conceito de voto vazio em um sentido distinto daquele usualmente aplicado na literatura sobre o assunto. Black considerou como voto vazio (empty voting) o exercício do direito de voto sem que haja qualquer interesse econômico (ou havendo interesse negativo) sobre a matéria sujeita a deliberação, ${ }^{22}$ ainda que não seja exatamente a exposição econômica decorrente da titularidade de ações. Hu, por outro lado, concluiu que, como Mason Capital tinha interesse apenas na diferença de preços entre as duas classes de ações e continua sem suportar a exposição econômica relacionada às ações emitidas pela Telus, de forma que não poderia ser considerado que tinha uma exposição econômica com relação à sociedade.

A posição defendida por $\mathrm{Hu}$ prevaleceu, conforme decisão da Suprema Corte da Colúmbia Britânica.

O caso não só ilustra as possíveis discussões e os problemas relacionados a um dos novos mecanismos de compra de votos, o empty voting, mas também evidencia as complexidades relacionadas à aplicação prática dos conceitos envolvidos, uma vez que seus próprios sistematizadores, Hu e Black, chegaram a conclusões opostas sobre o caso.

\section{A condição de acionista e o feixe de direitos e obrigações dela decorrente}

O estado de acionista, seu status socii, reconhecidamente garante-lhe direitos e deveres especiais, ${ }^{23}$ de natureza tipicamente societária, que o acompanham durante todo o período em que permanece integrante do quadro social da companhia.

${ }_{21}$ O caso e seus desdobramentos são analisados no artigo Ringe (2013a, p. 154-156), além dos artigos de Hu e Black.

22 Black (2012, p. 4). O conceito de empty voting será mais bem detalhado no capítulo IV.1.1, abaixo.

23. A classificação dos efeitos na esfera jurídica do acionista decorrentes do status socii nas categorias jurídicas de direitos, faculdades, poderes, ônus, obrigações e deveres foge ao escopo deste trabalho e, portanto, faz-se referência, genericamente, a direitos e deveres dos acionistas, sem que se averigue de forma minuciosa a natureza jurídica de cada um deles. 
Dentre os direitos e obrigações atrelados a essa posição jurídica, a distinção entre direitos políticos e patrimoniais, bem como a análise de sua titularidade e exercício, são de especial relevância para fins deste estudo.

\subsection{A qualidade de sócio (status socii)}

A posição jurídica de acionista - a qualidade de sócio ou status socii ${ }^{24}$-, decorre da titularidade de ações emitidas pela companhia ${ }^{25}$ e atribui àquele que a assume um conjunto especial de direitos e deveres, ${ }^{26}$ tanto em relação à companhia em si, quanto perante os demais integrantes da sociedade por ações, inclusive outros acionistas e os órgãos de sua administração. ${ }^{27}$

O estado de sócio é, nesse sentido, a premissa - necessária e suficiente - para que as relações jurídicas que envolvem o acionista, investido em sua qualidade especial de membro da companhia, possam ser posteriormente estabelecidas. ${ }^{28} \mathrm{~A}$ aquisição e a manutenção de seu estado de sócio são, em si mesmas, um direito do acionista, ${ }^{29}$ seu "direito fundamental", 30 "droit de faire partie de la société"31 ou "il diritto alla qualità di socio". 32

O status especial do acionista, mais do que uma particularidade das sociedades por ações, decorre, em verdade, da natureza elementar do contrato de sociedade, enquanto comunhão ${ }^{33}$ de esforços destinado ao exercício de atividade comum,

24 O enquadramento da posição de sócio como status é de Ascarelli (1936, p. 113); especificamente em relação às sociedades anônimas, rechaçando a distinção dualista entre direitos reais e direitos obrigacionais, diante da complexidade dos efeitos decorrentes da posição de acionista, cf. Ascarelli (1945, p. 393). A concepção é igualmente adotada por outros autores, a exemplo de Leães (1969, p. 302-303), que define este status como "posição de sócio dentro da coletividade social", e de Menezes Cordeiro (2007, p. 569), que trata da “"qualidade originária de sócio". Na literatura alemã, o conceito encontra seu paralelo na Mitgliedschaft, ou contrato de associação (cf., e.g., HUECK; CANARIS, 1986, p. 215; WIEDEMANN, 1965).

25 Sobre a vinculação dos direitos de sócio à ação, e não à pessoa do acionista, é expressiva a afirmação de Ferreira (1961, p. 306): "Engrenam-se na sociedade como órgãos no organismo, valendo nêle o que valem as ações, partes alíquotas do capital societário: mais vale a ação do que o acionista". Cf. também Soprano (1923, p. 31): "La persone ed i nome dei soci qui hanno poca o nessuna importanza".

26 A partir do momento em que o acionista se reveste do estado de sócio, adquirem-se, efetivamente, os direitos e obrigações no interior da sociedade - tem-se, portanto, o "nascimento da vida societária para o acionista" (ROBERT, 2016, p. 23).

27 Ilustrativa a denominação nostra res agitur atribuída ao dever estrutural dos sócios perante o interesse comum, derivado do contrato de sociedade (cf. MARTINS-COSTA, 2015, p. 350).

28 Comparato $(1978$, p. 77 ) apresenta o estado de sócio como prius das demais relações jurídicas especiais a ele relacionadas e que dele decorrem, não obstante autônomas e com ele inconfundíveis.

29 Em sentido contrário, cf. Leães (2004a, p. 69), que afirma que a qualidade de sócio é uma situação jurídica, e não um direito subjetivo do sócio.

30 A expressão é de Comparato (1990, p. 123).

31 Cf. Ripert e Roblot (1968, p. 629).

32 Cf. Buonocore (1960, p. 172).

33 Não se utiliza o termo "comunhão" como sinônimo de "condomínio", no sentido jurídico do termo, mas 
com a respectiva partilha dos resultados entre aqueles que contribuíram com seus recursos para tal atividade. ${ }^{34}$

As relações jurídicas relacionadas ao status especial do acionista, por sua vez, envolvem direitos e deveres especiais, de natureza tipicamente societária, ${ }^{35}$ que regulam o funcionamento interno da companhia e garantem seu equilíbrio interna corporis. Esses direitos e deveres dos acionistas são estruturados em favor dos objetivos de preservação da sociedade ${ }^{36}$ e de promoção do fim social, ${ }^{37}$ tido como "der Polarstern des Gesellschaft" (a estrela polar da sociedade), ${ }^{38}$ e constituem os fundamentos mais básicos das sociedades.

Nesse sentido, pode-se dizer que, nas sociedades por ações, o acionista tem o dever primordial de contribuir com seus recursos para a atividade empresarial, ${ }^{39}$ estando sua responsabilidade restrita ao montante investido. ${ }^{40} \mathrm{~A}$ contribuição pode ocorrer de forma direta, por meio da subscrição de ações recém-emitidas pela companhia ou da aquisição de ações ainda não integralizadas, ou indireta, por meio da aquisição de ações já

apenas para indicar o escopo comum e recíproco da contribuição dos participantes do contrato de sociedade. Como adverte Ferreira (1927, p. 29), ressaltando a personificação da sociedade em entidade distinta de seus sócios: "Não se fórma uma comunhão [...] uma vez perfeito o contracto de sociedade, isto é, prestado o consentimento de todos os socios, ipso facto e ipso jure, surge uma pessoa metaphysica, fictícia [...]”.

34 Ver a definição de sociedade apresentada pelo art. 981, do Código Civil, aplicável de forma integral a todas e quaisquer sociedades, independentemente do tipo societário adotado em casa caso: "Celebram contrato de sociedade as pessoas que reciprocamente se obrigam a contribuir, com bens ou serviços, para o exercicio de atividade econômica e a partilha, entre si, dos resultados", a qual está presente, i.a., em Vivante (1922, p. 64). Cf. Ferrara e Corsi (1994, p. 253), de acordo com quem os três elementos distintivos do contrato de sociedade são: $(i)$ conferência de recursos pelos sócios; (ii) exercício de atividade econômica em comum; e (iii) escopo de lucro. Comparato (1990, p. 150), por sua vez, afirma serem as sociedades os "protótipos dos contratos plurilaterais", cujo elemento essencial é a comunhão de escopo entre seus partícipes. Para maior aprofundamento sobre a natureza do contrato de sociedade, vide também Ascarelli (1955, p. 327-328) e Sztajn (1989, p. 30-52).

35 A afirmação não significa, contudo, que as normas gerais deixem de ser aplicáveis a tais relações jurídicas, estabelecidas entre acionistas e demais envolvidos no funcionamento das companhias. São aplicáveis, ainda, as normas de direito comum e eventuais disposições contratuais, dentro dos limites da liberdade contratual, a exemplo daquelas estabelecidas em acordos de acionistas. Apresentando essas três ordens de normas, especificamente quanto à origem dos direitos aos acionistas, vide Robert (2011, p. 50).

36 A perenidade é elemento fundamental das sociedades por ações, conforme nota Forgioni (2011), afirmando ser a estabilidade a "diferença profunda" que levou ao seu regramento especial das sociedades por ações frente aos demais tipos societários, desde o Código Comercial de 1850.

37 Cf. Robert (2011, p. 39).

38 Cf. Wiedemann (2004, p. 122). Para a discussão sobre a superação da ideia de affectio societatis pelo conceito de fim social, vide França (2009, p. 27-68). Cf. também, para discussão sobre o interesse social e as teorias para sua identificação, Salomão Filho (2015, p. 153-177).

39 Vide Pontes de Miranda (1984, p. 215) e Carvalho de Mendonça (1963, p. 31).

40 A limitação da responsabilidade dos acionistas é apontada por Hansmann e Kraakman (2004, p. 5-15) como uma das cinco características básicas das companhias (corporations, no original), ao lado da personificação da sociedade, da livre circulação das ações, delegação da administração e propriedade de investidores. 
integralizadas de outros acionistas - considerando-se indireta a contribuição, neste caso, pelo fato de os recursos despendidos pelo ingressante não se destinarem à companhia.

O acionista assume também outros deveres, a exemplo dos deveres de lealdade, cooperação com a companhia e atuação constante em consonância com o interesse social. ${ }^{41}$ Deve observar, ainda, as regras especiais que derivam de seu dever geral de lealdade, a exemplo da disciplina de conflito de interesses, benefício particular e abuso de direito de voto, ${ }^{42}$ bem como, no caso do regramento próprio das companhias abertas, das regras relativas à vedação a insider trading, fraude, manipulação de mercado e práticas não equitativas. ${ }^{43}$

De outro lado, ao acionista é atribuída uma vasta gama de direitos, os quais podem ser categorizados de diversas maneiras, de acordo com os critérios adotados na classificação, tendo em vista os objetivos pretendidos em cada caso. ${ }^{44}$

41 Cf. Robert (2016, p. 24). Ressalta-se que excede o escopo deste trabalho a discussão acerca da caracterização de "interesse social". Ver, sobre o tema, França (1993, p. 21-53), para apresentação das teorias contratualistas e institucionalistas sobre a definição do interesse social; e Salomão Filho (2011, p. 27-52), para apresentação sintética das teorias contratualista, institucionalista e, ainda, organizativa, sendo esta última defendida pelo referido autor.

42 Ver art. 115, da Lei das Sociedades por Ações, que trata do exercício abusivo do direito de voto, conflito de interesses e benefício particular nas deliberações assembleares ("O acionista deve exercer o direito a voto no interesse da companhia; considerar-se-á abusivo o voto exercido com o fim de causar dano à companhia ou a outros acionistas, ou de obter, para si ou para outrem, vantagem a que não faz jus e de que resulte, ou possa resultar, prejuízo para a companhia ou para outros acionistas"); e, em relação especificamente ao acionista controlador, art. 117, § $1^{\circ}$, "a", da Lei das Sociedades por Ações, que dispõe sobre o exercício abusivo do poder de controle ("São modalidades de exercício abusivo de poder: a) orientar a companhia para fim estranho ao objeto social ou lesivo ao interesse nacional, ou levá-la a favorecer outra sociedade, brasileira ou estrangeira, em prejuízo da participação dos acionistas minoritários nos lucros ou no acervo da companhia, ou da economia nacional').

$43 \mathrm{Cf}$. art. $155, \S 4^{\circ}$, da Lei das Sociedades por Ações ("É vedada a utilização de informação relevante ainda não divulgada, por qualquer pessoa que a ela tenha tido acesso, com a finalidade de auferir vantagem, para si ou para outrem, no mercado de valores mobiliários"), art. 4, IV, "c", da Lei n. 6.385/1976 ("O Conselho Monetário Nacional e a Comissão de Valores Mobiliários exercerão as atribuições previstas na lei para o fim de: [...] IV-proteger os titulares de valores mobiliários e os investidores do mercado contra: [...] c) o uso de informação relevante não divulgada no mercado de valores mobiliários") e Instrução CVM n. 358/2002 (dispondo sobre a vedação à negociação com informação privilegiada); e art. $4^{\circ}$, V e VII, da Lei n. 6.385/1976 ("O Conselho Monetário Nacional e a Comissão de Valores Mobiliários exercerão as atribuições previstas na lei para o fim de: [...] V-evitar ou coibir modalidades de fraude ou manipulação destinadas a criar condições artificiais de demanda, oferta ou preço dos valores mobiliários negociados no mercado; [...] VII - assegurar a observância de práticas comerciais equitativas no mercado de valores mobiliários") e Instrução CVM n. 8/1979 (regulando a proibição a fraude, manipulação de mercado e demais práticas não equitativas no mercado de capitais). Ver também Ostler (2010, p. 53-54), que trata do acionista como destinatário das normas do mercado de capitais, sendo-lhe vedados, por consequência, as práticas de insider trading e manipulação de mercado.

44 Sobre a diversidade de classificações possíveis e dificuldade de classificação, vide Ascarelli (1945, p. 405) e Bulgarelli (1998, p. 48-54). Ressalta-se, ainda, que as classificações dos direitos dos acionistas podem, ainda, se sobrepor, acrescentando ainda maiores dificuldades a esta tarefa: por exemplo, Teixeira e Guerreiro (1979, p. 278-279) tratam dos direitos essenciais dos acionistas como uma segunda denominação dos direitos individuais ou direitos próprios dos acionistas. 
São critérios possíveis para categorização dos direitos dos acionistas, por exemplo: $(i)$ a titularidade e a forma de exercício do direito (coletiva, individual ou particular); ${ }^{45}$ (ii) o momento de exercício do direito ou cumprimento da obrigação (a qualquer momento, em determinado prazo, durante os trabalhos da assembleia, etc.); (iii) o caráter essencial ou não do direito; ${ }^{46}$ e (iv) a natureza dos direitos e obrigações envolvidos, nesse caso com a recorrente divisão em duas categorias - direitos patrimoniais (ou econômicos) e políticos ${ }^{47}$-, ou maior número, conforme a especificidade pretendida na classificação. ${ }^{48}$

$\mathrm{O}$ acionista permanece titular de tais direitos e deveres especiais enquanto perdurar sua condição de sócio - observada, ainda, a sobrevivência dos direitos de ação a eles relacionados pelo respectivo prazo de prescrição. Portanto, o estado especial do acionista, com direitos e deveres dele decorrentes, perdura até a dissolução total ou parcial da sociedade, esta última tida como a resolução em qualquer das hipóteses previstas em lei (retirada, regaste, exclusão, etc.) ou, ainda, em caso de alienação ou expropriação da totalidade das ações por ele detidas. ${ }^{49}$

45 Cf., i.a., Carvalho de Mendonça (1963, p. 456-460), que reporta a distinção feita pela doutrina alemã, a partir da titularidade dos direitos decorrentes da condição de sócio, entre direitos de coletividade (Kollectiverechte), direitos individuais (Individualrechte) e direitos particulares (Sonderrechte) dos acionistas; e Pontes de Miranda (1984, p. 229), por sua vez, diferencia os "direitos individuais" (direito aos dividendos, por exemplo) dos "direitos de natureza social" (i.a., a participação e o voto em assembleia).

46 Trata-se da distinção entre os direitos essenciais do acionista, previstos no art. 109 da Lei das Sociedades por Ações, e os direitos que podem ser restringidos ou suprimidos pelo estatuto social ou pela assembleia geral, conforme o caso. Ressalta-se que o direito de voto não se inclui dentre os direitos essenciais do acionista; $\mathrm{e}$ não poderia ser diferente, uma vez que a própria Lei das Sociedades por Ações admite a existência de ações preferenciais sem direito de voto ou com direito de voto restrito, conforme seu art. 111. É certo que, embora não seja um direito essencial do acionista, o voto não está desvinculado do status socii, como aponta Robert (2015, p. 52): "Dizer que o direito de voto não é essencial não significa dizer, no entanto, que o direito de voto não seja inerente ao estado de sócio".

47 Carvalho de Mendonça (1963, p. 69-71) faz sua categorização entre o "direito patrimonial" e o "direito pessoal" do acionista, este último referente aos seus direitos políticos, apesar de reconhecer a impossibilidade de apresentação sistemática de todos os direitos e obrigações decorrentes da posição de sócio. Cf. também, i.a., Vigreux (1953, p. 9), que distingue entre direitos políticos e direitos patrimoniais dos acionistas e Escarra, Escarra e Rault (1955, p. 2-3), que acrescentam as "prerrogativas de ordem judicial" às "prerrogativas de ordem pecuniária" e "prerrogativas de governo".

48 Por exemplo, Clark (1986, p. 93) divide os direitos dos acionistas em três grupos: direito de voto; direito de ação; e direito à informação; e Robert (2011, p. 38 e 41-45) faz a seguinte distinção: direitos de participação na administração, direitos de fiscalização, direitos patrimoniais e direitos dissolutórios.

49 Buonocore (1960, p. 192-200) diferencia as hipóteses de cessação do status de sócio de acordo com sua origem: (i) por vontade própria do acionista (retirada e alienação da totalidade das ações por ele detidas); (ii) por vontade da companhia (ações caídas em comisso, devido à não integralização); ou, ainda, (iii) por vontade de terceiros (expropriação). Sobre a dissolução de sociedades, cf. Penteado (2000). 


\subsection{Direitos patrimoniais e políticos dos acionistas}

Os direitos do acionista, decorrentes de seu status especial, conforme mencionado acima, podem ser classificados de diversas maneiras. Para fins deste estudo, é relevante a distinção entre: $(i)$ de um lado, seus direitos patrimoniais, especialmente o direito de participar nos resultados econômicos positivos (lucros sociais) $;^{50}$ e (ii) de outro lado, seus direitos políticos, em especial, o direito de voto, ${ }^{51}$ que pode ser tido como a síntese dos demais direitos políticos dos acionistas, ${ }^{52}$ incluindo a participação em assembleias $^{53}$ e seus direitos fiscalizatórios. ${ }^{54}$

Apesar de suas naturezas distintas, esses dois conjuntos de direitos mostramse inter-relacionados no âmbito interno das companhias. A associação entre os direitos patrimoniais e políticos dos acionistas é até mesmo apontada como uma das premissas basilares da governança corporativa moderna. ${ }^{55}$

Nesse sentido, os direitos políticos e, principalmente, o direito de voto - i.e., o direito de participar na formação da vontade social ${ }^{56}$ da companhia, enquanto entidade destacada de seus sócios - é fundamentado na posição econômica que os

50 Para aprofundamento sobre os direitos patrimoniais dos acionistas, em especial quanto ao direito ao lucro e ao direito ao dividendo, ver Robert (2011), especialmente p. 37-80; e, quanto aos direitos de participação no acervo em caso de liquidação, vide Penteado (2000), especialmente p. 76-78 e 203-206.

51 Interessante notar que o direito de voto pode ser apresentado como a principal forma de manifestação dos demais direitos dos acionistas (ROBERT, 2016, p. 25). Não se discute, neste trabalho, a natureza jurídica do voto - se direito, dever, ônus, ou outra classificação. Para tanto, cf., i.a., Ascarelli (1962, p. 491); Carvalho de Mendonça (1959, p. 27) (conferindo ao voto em assembleia a natureza jurídica de poder); Ripert e Roblot (1968, p. 632) (entendendo tratar-se de um direito individual do acionista, e não um direito-função); Sena (1961, p. 123-161) (pela definição do direito de voto como um direito subjetivo coletivo); Pontes de Miranda (1984, p. 229) (defendendo tratar-se de ônus); ou, ainda, Teixeira e Guerreiro (1979, p. 277) (voto caracterizado como "direito limitado por preceito imperativo", relativo ao exercício no interesse da companhia).

52 Cf. Robert (2016, p. 12).

53 Trata-se, portanto, não apenas da manifestação do voto em si, mas também da participação nos debates em assembleia, da formulação de questionamentos à administração, aos auditores e aos demais presentes, da apresentação de protestos e manifestações, e, de forma geral, da ampla participação da assembleia geral, que integram o processo de formação de vontade social, diferente e mais complexo que a mera soma dos votos afirmativos, negativos e abstenções. Sobre a importância das discussões em assembleia, cf., i.a., Sena (1961, p. 407-410).

54 Hu e Black, em geral, também se restringem à dissociação entre direitos patrimoniais e direitos de voto e de participação em assembleias gerais em seus artigos, embora reconheçam, na segunda geração de seus trabalhos, a possibilidade de dissociação entre os mais variados direitos decorrentes da posição de acionista (HU; BLACK, 2008a, p. 721-728; HU; BLACK, 2008b, p. 14). No mesmo sentido, distinguindo os Vermögenrechten (direitos patrimoniais) dos Verwaltungrechten (direitos políticos, de participar na formação da vontade social), cf. Tautges (2016, p. 37-38).

55 A premissa é apresentada ao lado da separação entre propriedade e controle, também tida como premissa fundamental da governança corporativa moderna (HU; BLACK, 2007, p. 1).

56 Em metáfora sobre a formação da vontade social, Sztajn (1982, p. 7) afirma ser a assembleia geral "o 'cadinho' em que se fundem as vontades individuais dos acionistas a fim de se manifestar a vontade coletiva ou 'vontade social"'. 
acionistas assumem perante a companhia: de proprietários residuais, ${ }^{57}$ titulares de direitos patrimoniais sobre a companhia que lhes garante a partilha dos resultados positivos.

Ou seja, os acionistas são aqueles que, no limite, suportam o risco da atividade empresarial desenvolvida. ${ }^{58}$ Não obstante sua responsabilidade direta limite-se às entradas integralizadas, os acionistas suportam o risco das atividades na medida em que podem perder completamente o investimento realizado, sem ter qualquer retorno, caso os ativos da sociedade não sejam suficientes para quitar todos os passivos sociais. Os acionistas podem, dessa forma, ser considerados os "proprietários econômicos" da companhia, ${ }^{59} \mathrm{e}$, por essa razão, é razoável que eles possuem o poder decisório em última instância sobre os negócios sociais. ${ }^{60}$

O raciocínio retorna e se embasa, novamente, no conceito do contrato de sociedade. A partir do momento em que constituem uma sociedade, seus sócios podem, como premissa, definir, por meio do exercício de seu direito de voto, o objeto e o modus operandi das atividades dessa mesma sociedade, para os quais serão vertidos os recursos aportados. ${ }^{61}$ No caso das sociedades por ações, dada a natureza empresarial do tipo, ${ }^{62}$

57 O raciocínio é bem explicado por Easterbrook e Fischel (1983, p. 403-406), os quais concluem que os acionistas, na condição de proprietários residuais, têm os incentivos apropriados para tomar as decisões em última instância nas companhias: "The right to vote (that is, the right to exercise discretion) follows the residual claim".

58 Cf., i.a., Vivante (1923, p. 231); Vigreux (1953, p. 16) e Ferreira (1961, p. 321-322).

59 Tanto é assim que Hansmann e Kraakman (2004, p. 13) apresentam o direito de controlar a empresa e o direito de receber os lucros oriundos de suas atividades como os dois elementos fundamentais da propriedade sobre a empresa. Ressalte-se que a caracterização dos acionistas como "proprietários econômicos" não é isenta de críticas, as quais aduzem haver confusão no uso de categoria dos direitos reais (propriedade) ao tratar de relação eminentemente societária, do acionista perante a companhia da qual participa (cf. OSTLER, 2010, p. 34). Em sentido econômico, contudo, é possível afirmar que se trata de direito de propriedade, como apontam Hansmann e Kraakman: "A security interest is a property right in our sense because, to a greater or lesser degree, it is enforceable against subsequent transferees of rights in the asset, including other transferees of security interests". Os autores discutem, ainda, a divisibilidade dos direitos relacionados a determinado ativo, inclusive diante do fenômeno de anticommons (HANSMANN; KRAAKMAN, 2002, p. 403-405). Para discussão sobre anticommons, ver: Michelman (2003, p. 663 et seq.) e Heller (1998, p. 622 et seq.).

60 Hansmann (1996, p. 35) apresenta o exercício do controle e o direito de receber as receitas residuais como dois atributos da propriedade, explicando, do ponto de vista econômico, a relação existente entre os direitos políticos e patrimoniais dos acionistas.

${ }_{61}$ Lamy Filho e Pedreira (1996, p. 293-294) esclarecem que o princípio de que o direito de voto é conferido para permitir a participação do acionista na formação da vontade social está implícito no art. 115 da Lei das Sociedades por Ações, que prescreve o exercício do direito de voto ao encontro do interesse da companhia. Os autores defendem, ainda, que a "funcionalidade" da companhia pressupõe o exercício do voto no interesse da companhia, sendo o voto instrumento de ação coletiva voltado para a consecução dos fins comuns.

62 Cf. art. 982, parágrafo único, do Código Civil, que prevê serem as sociedades por ações empresariais pela forma. Sobre a comercialidade das sociedades por ações e respectivas alterações legislativas, vide Marcondes (1970, p. 166-168); em favor da comercialidade pela forma, Valverde (1941, p. 48-49); e, em sentido contrário, Ferreira (1958, p. 991-993). 
trata-se especificamente da determinação do funcionamento da empresa ${ }^{63}$ - ou da "técnica jurídica de organização da empresa" ${ }^{64}$

Os acionistas, dessa forma, por meio do exercício de seus direitos políticos possibilitam a "execução contínua do contrato de sociedade" e paulatinamente preenchem as incompletudes encontradas em seu funcionamento, por meio das deliberações sociais, em prol do objetivo social de lucro e de sua respectiva partilha. ${ }^{65}$

Os direitos políticos dos acionistas - em especial, o direito de voto -, portanto, assumem a função instrumental de preservação de seus direitos patrimoniais e do objetivo último das sociedades por ações: a obtenção e partilha de lucros entre os sócios. ${ }^{66}$

Da inter-relação existente entre os direitos patrimoniais e os direitos políticos deriva, ainda, o princípio da proporcionalidade, de acordo com o qual os direitos políticos dos acionistas são medidos por sua contribuição ao capital social ${ }^{67}$ e que, em regra, prevalece nas sociedades por ações. ${ }^{68}$ A proporcionalidade dos direitos dos acionistas

63 Para análise da natureza da empresa, faz-se referência, i.a., Asquini (1943); Ferreira (1955, p. 35-42); Ascarelli (1962, p. 161-185); Marcondes (1970, p. 1-40); Bulgarelli (1985); Requião (1973, p. 41-52) e Sztajn (2004, p. 173-225).

${ }^{64}$ A construção da expressão de técnica jurídica de organização é de Paillusseau (1967).

${ }_{65}$ Cf. Robert (2016, p. 12-16), especialmente p. 12-13. Sobre o tema da incompletude, ver também Sztajn (2013, p. 215 et seq.).

${ }_{66}$ Nesse sentido, especialmente sobre o direito de voto, explica Robert $(2015$, p. 51) que "o voto, nesse sentido, é mero instrumento, de caráter explicitamente indireto, para o aperfeiçoamento dos direitos que são essenciais ao estado de sócio. $O$ direito de voto e seu exercício são necessários, portanto, não para a existência da sociedade, mas tão somente na medida de sua necessidade para a preservação e materialização dos direitos que são fundamentais para a existência da sociedade", podendo ser considerado como um dos meios para garantia dos direitos essenciais, nos termos do art. 109, § $2^{\circ}$, a Lei das Sociedades por Ações ("Os meios, processos ou ações que a lei confere ao acionista para assegurar os seus direitos não podem ser elididos pelo estatuto ou pela assembleia-geral").

${ }^{67}$ Cf. Pela (2012, p. 126).

68 O princípio da proporcionalidade foi bastante discutido no processo administrativo CVM n. RJ 2013/5993 (caso Azul), de relatoria da diretora Ana Dolores Moura Carneiro de Novaes. No caso em questão, o colegiado da autarquia decidiu que a existência de ações preferenciais emitidas pela Azul S.A. com direitos econômicos equivalentes a 75 vezes os direitos econômicos das ações ordinárias emitidas pela mesma companhia não viola o art. $15, \S 2^{\circ}$, da Lei das Sociedades por Ações [“Art. 15. [...] $\$ 2^{\circ} O$ número de ações preferenciais sem direito a voto, ou sujeitas a restrição no exercicio desse direito, não pode ultrapassar $50 \%$ (cinquenta por cento) do total das ações emitidas"], contrariando a opinião da área técnica (constante do RA/CVM/SEP/GEA-2/N. 131/2013) e o parecer da Procuradoria Federal Especializada (Parecer/N. 009/2013/PFE-CVM/PGF/AG). A relatora, em seu voto, foi expressa ao considerar que o princípio da proporcionalidade não é cogente ("no meu entendimento, não é necessário que haja uma correspondência entre o aporte econômico trazido pelo acionista e o poder político que ele exerce na companhia") e também mencionou os fenômenos de hidden ownership e empty voting objeto deste trabalho ("Observe-se que o uso de derivativos pode levar a situações nas quais o poder político é maior do que o interesse econômico (o chamado empty voting) ou, o contrário, o interesse econômico medido pelo fluxo de caixa é maior do que o poder político (propriedade escondida ou hidden ownership"). A diretora Luciana Dias, na mesma ocasião, em sua declaração de voto, reconheceu a existência dos fenômenos, em especial por consequência do uso de derivativos e empréstimo de ações ("utilização de contratos que alocam a exposição econômica 
frente a suas respectivas contribuições à companhia, nesse sentido, significa tanto a medida de seus direitos, quanto a atribuição de determinados direitos especiais apenas a titulares de determinada participação na companhia $(5 \%, 10 \%, 15 \%$, do capital social total ou de determinada espécie e classe de ações, conforme o caso). A proporcionalidade entre entradas dos acionistas e seu poder nas sociedades, nesse aspecto, representa uma das implicações concretas da função estrutural ou organizativa do capital social, aplicável interna corporis. ${ }^{6}$

A proporcionalidade não integra, contudo, o núcleo do tipo sociedade por $a c ̧ \tilde{e} e s,{ }^{70}$ como se observa pela possibilidade de limitação ao direito de voto ${ }^{71}$ e emissão de ações preferenciais sem determinados direitos, ${ }^{72}$ golden shares ${ }^{73} \mathrm{e}$, de forma geral, ações de classes diversas com direitos distintos entre si. ${ }^{74}$ Embora não seja inderrogável, nem essencial nas sociedades por ações, o princípio da proporcionalidade, especialmente se considerado na perspectiva de igualdade de direitos conferidos por uma mesma espécie e classe de ações, ${ }^{75}$ é relevante para a dinâmica interna das companhias.

Com relação ao direito de voto e manifestação em assembleia, a proporcionalidade concretiza-se no princípio bastante difundido de one share, one vote

para um sujeito e os direitos políticos para outro, tais como derivativos ou contratos de empréstimos de ações"). A matéria foi discutida novamente pela Superintendência de Relações com Empresas (SEP) por ocasião da análise das alterações propostas pela Bolsa de Valores nos regulamentos de listagem dos níveis especiais de governança corporativa que acomodariam "estruturas alavancadas de controle", como aquelas observadas no caso Azul e na reestruturação societária da Gol Linhas Aéreas Inteligentes S.A., em que as ações ordinárias foram desdobradas na razão de 1:35 e determinados direitos das ações preferenciais foram multiplicados em 35 vezes (RA/CVM/GEA-2/N. 148/2015).

69 Sobre a função organizativa do capital social, em oposição à tradicional função de proteção de credores, que opera externa corporis, vide Penteado (1988, p. 29-31). Ver também, para estudo abrangente sobre o capital social, Manning (1981).

70 Cf., sobre os elementos do tipo "sociedade anônima", considerando a função do instituto, Pela (2012, p. 111-114).

71 Ver art. $110, \S 1^{\circ}$, da Lei das Sociedades por Ações: "O estatuto pode estabelecer limitação ao número de votos de cada acionista”. Cf., sobre o tema, Robert (2016, p. 140-144).

72 Cf. art. 111, caput, da Lei das Sociedades por Ações ("O estatuto poderá deixar de conferir às ações preferenciais algum ou alguns dos direitos reconhecidos às ações ordinárias, inclusive o de voto, ou conferi-lo com restrições, observado o disposto no artigo 109"). Sobre o assunto, ver Bebchuk, Kraakman e Triantis (2000).

73 Cf. art. $17, \S 7^{\circ}$, da Lei das Sociedades por Ações ("Nas companhias objeto de desestatização poderá ser criada ação preferencial de classe especial, de propriedade exclusiva do ente desestatizante, à qual o estatuto social poderá conferir os poderes que especificar, inclusive o poder de veto às deliberações da assembleia-geral nas matérias que especificar"). Para estudo extensivo sobre as golden shares, cf. Pela (2012).

74 A constatação decorre da circunscrição do princípio da igualdade dos acionistas no âmbito de cada espécie e classe de ações, de acordo com o art. 109, $\S 1^{\circ}$, da Lei das Sociedades por Ações ("As ações de cada classe conferirão iguais direitos aos seus titulares").

75 Como nota Paillusseau (1967, p. 43), o princípio da proporcionalidade entre os acionistas transformou-se no princípio de igualdade de direitos conferidos pelas ações. 
(por vezes relacionado à expressão "democracia acionária"76). ${ }^{77}$ Também neste caso, não se trata de princípio societário inderrogável - conforme previsão legal expressa, que permite a limitação do número de votos dos acionistas, per capita $^{78}$-, nem de uma constante na história das sociedades por ações, ${ }^{79}$ embora o conceito seja relevante, em regra, para o funcionamento interno das sociedades por ações.

\subsection{Titularidade e exercício dos direitos e obrigações decorrentes da condição de sócio}

O conjunto de direitos e obrigações decorrentes do estado de sócio é usualmente tido como um bloco incindível, um "pacote inicial" 80 inerente a essa condição especial, cujos componentes, em princípio, não se podem separar, de forma a manter o risco e o poder respectivo devidamente associados. ${ }^{81}$ Trata-se da premissa de incindibilidade (não necessariamente correta, como se apresentará abaixo), de acordo com a qual a titularidade e exercício de tais direitos e obrigações se concentram no acionista e não podem dele se separar, como consequência de seu estado de sócio e titular de participação societária na companhia.

A premissa de incindibilidade tem reflexos importantes na dinâmica interna das sociedades por ações e deu origem a relevantes debates doutrinários, por exemplo, sobre a licitude de acordos de acionista que dispusessem sobre direito de voto.

76 Para esclarecimentos sobre a expressão, diante do desenvolvimento histórico das sociedades por ações, cf. Galgano (2010, p. 160-171).

77 O princípio encontra-se previsto no art. 110, da Lei das Sociedades por Ações: “A cada ação ordinária corresponde 1 (um) voto nas deliberações da assembleia-geral". O princípio também é indicado no Código de Melhores Práticas de Governança Corporativa do Instituto Brasileiro de Governança Corporativa (IBGC) (princípio 1.1), sob a justificativa de ser a estrutura que mais promove alinhamento de interesses. Para uma crítica à eficiência do modelo, tendo em vista o mercado de derivativos e a possibilidade de dissociação dos direitos políticos dos direitos patrimoniais, como será adiante tratado neste trabalho, ver Kalay e Pant (2009).

78 Cf. art. 110, $\S 1^{\circ}$, da Lei das Sociedades por Ações: "O estatuto pode estabelecer limitação ao número de votos de cada acionista", apesar de não ser possível a atribuição de voto plural, de acordo com o $\S 2^{\circ}$ do mesmo artigo ("É vedado atribuir voto plural a qualquer classe de ações"). Sobre a flexibilidade e derrogabilidade do princípio, vide Robert (2016, p. 20-23). Cf. também, quanto à analogia, do ponto de vista prático-econômico existente entre, de um lado, a atribuição de voto plural às ações e, de outro, à retirada do direito de voto de determinadas ações, de outro, Ascarelli (1945, p. 66).

79 O princípio da proporcionalidade, apesar de ser atualmente preponderante, não foi uma constante na história das companhias. Para breve histórico, principalmente nos Estados Unidos, cf. Martin e Partnoy (2005, p. 781-782) e Black e Kraakman (1996, p. 1.943-1.952). Cf., ainda, Hansmann e Pargendler (2014), que explicam a difusão de estruturas distintas do princípio de one share, one vote em sociedades no século XIX.

${ }^{80}$ A expressão é de Robert (2015, p. 52), que afirma: "Originalmente, o voto está atrelado à ação ou quota, consistindo em um dos direitos, deveres e obrigações que compõem o pacote inicial assumido por cada sócio".

81 Cf. Pedrol (1969, p. 174 et seq.). 
Nesse sentido, muito se discutiu sobre a validade de acordos de acionistas que dispusessem sobre o exercício do direito de voto, sob a alegação de impossibilidade de sua vinculação e disposição por meio de contratos particulares, por ser um direito inerente à condição de sócio. Atualmente, não há mais dúvidas doutrinárias acerca da possibilidade de disposição contratual, por meio de acordos de acionistas, acerca do direito de voto, ${ }^{82} \mathrm{o}$ que se mostra, além disso, realidade constante e consolidada na prática societária. ${ }^{83}$

A premissa também fundamentou regras atualmente presentes na disciplina societária, a exemplo das limitações à legitimação para representação de acionistas em assembleia e vedação à negociação de votos.

Sobre a representação de acionistas em assembleias, ${ }^{84}$ anteriormente à atual Lei das Sociedades por Ações, apenas outros acionistas poderiam representar seus pares em assembleias, ${ }^{85} \mathrm{sob}$ o fundamento de que seria necessário algum nível de vinculação, por meio da titularidade de ações, entre o representante e a companhia em questão ${ }^{86} \mathrm{~A}$ lei atual, em linha com a tendência observada em outros países e em resposta ao absenteísmo dos acionistas, ${ }^{87}$ estendeu o rol de legitimados também a administradores da companhia e advogados, da mesma forma que, nas companhias abertas, instituições financeiras, ${ }^{88}$ incluindo instituição depositária de ações e administradores de carteira, ${ }^{89}$ bem como administradores e gestores de fundos de investimento..$^{90}$

82 Cf., i.a., Cottino (1958); Pedrol (1969); Sena (1961, p. 312 et seq.). No Brasil, vide, i.a., Carvalhosa (2011a, p. 93 et seq.), especialmente p. 115-116 (diferenciando a disposição do direito de voto de sua alienação, sendo esta última proibida, enquanto aquela é permitida); Barbi Filho (1993, p. 99 et seq.) e Comparato e Salomão Filho (2014, p. 184 et seq.).

83 Interessante notar os comentários dos autores do anteprojeto da Lei das Sociedades por Ações, ao tratarem da disciplina legal dos acordos de acionistas: "Recusou abrigo, dessa forma, o Anteprojeto, à tese dos juristas europeus de que 'voto está fora do comércio'- quando se compram as ações com voto - tese, aliás, já criticada pelos mais lúcidos, que não hesitam em proclamar que a Europa, nessa matéria, 'está na idade da pedra lascada"' (LAMY FILHO; PEDREIRA, 1995, p. 154-155).

${ }^{84}$ Sobre a representação dos acionistas, de forma geral, cf. Marcondes (1977, p. 31-54).

85 Cf. Robert (2016, p. 204).

86 Cf. a afirmação de Carvalhosa: "Não se admitia o seu exercício [do direito de voto] desacompanhado da titularidade, razão por que o voto por representante também requeria a qualidade de acionista do procurador" (CARVALHOSA, 2011b, p. 93).

87 Cf. Carvalhosa (2011b, p. 872-890). Levantando dúvidas quanto à conveniência de se permitir que administradores representem os acionistas em assembleia, cf. Teixeira e Guerreiro (1979, p. 398).

${ }_{88}$ A regra se encontra no art. $126, \S 1^{\circ}$, da Lei das Sociedades por Ações: “O acionista pode ser representado na assembleia-geral por procurador constituído há menos de 1 (um) ano, que seja acionista, administrador da companhia ou advogado; na companhia aberta, o procurador pode, ainda, ser instituição financeira, cabendo ao administrador de fundos de investimento representar os condôminos".

89 Cf. art. 25, da Lei n. 6.385/1976: "Salvo mandato expresso com prazo não superior a um ano, o administrador de carteira e o depositário de valores mobiliários não podem exercer o direito de voto que couber às ações sob sua administração ou custódia".

90 Ver art. 78, § 3, II, da Instrução CVM n. 555/2014: “A gestão da carteira do fundo é a gestão profissional, conforme estabelecido no seu regulamento, dos ativos financeiros dela integrantes, desempenhada por pessoa natural ou juridica credenciada como administradora de carteiras de valores mobiliários pela 
Recentemente, em relação às companhias abertas, a CVM estendeu ainda mais os legitimados a representar acionistas em assembleias, limitando seu escopo de aplicação aos acionistas pessoas naturais e, portanto, permitindo que acionistas pessoas jurídicas ou outras entidades, presentadas ${ }^{91}$ na forma de seus atos constitutivos, outorguem procurações a quaisquer terceiros, independentemente de sua relação com a companhia, profissão ou objeto social. ${ }^{92}$

Ainda em decorrência da premissa de incindibilidade de direitos inerentes à condição de sócio, vedou-se a negociação de votos em destacado da titularidade das ações que garantem seu exercício. ${ }^{93}$ A existência, quer na legislação societária, quer na legislação geral, da vedação quanto à possibilidade de cessão do direito de voto ${ }^{94}$ ou de quaisquer outros direitos decorrentes da condição de sócio, é, no entanto, questionável, conforme a interpretação que se atribua ao termo "negociar" constante do Código Penal. ${ }^{95}$

A premissa de incindibilidade dos direitos e obrigações decorrentes da condição de sócio trata-se, em verdade, de um "dogma"96 que acompanha a literatura

CVM, tendo poderes para: (...) II - exercer o direito de voto decorrente dos ativos financeiros detidos pelo fundo, realizando todas as demais ações necessárias para tal exercício, observado o disposto na política de voto do fundo".

91 Faz-se referência à distinção apresentada por Pontes de Miranda (1970, p. 412-415) quanto às figuras jurídicas de representação e presentação. Cf., no mesmo sentido, Costa (1976, p. 37 et seq.) e Costa (1977, p. 76 et seq.).

92 A mudança ocorreu a partir da decisão do colegiado da CVM, em reunião de 04.11.2014, no processo administrativo CVM n. RJ2014/3578 (caso Brookfield), de relatoria da diretora Ana Dolores Moura Carneiro de Novaes. A diretora afirmou em seu voto que "acredit[a] que permitir que as pessoas jurídicas possam se representar nas assembleias de companhias por meio de seus representantes legais, podendo ainda se representar, através de mandatários devidamente constituidos, de acordo com os atos constitutivos da sociedade e com as regras do Código Civil, é a melhor interpretação do art. 126 e seus parágrafos". $\mathrm{O}$ entendimento adotado pela CVM não se limitou ao caso em questão e foi refletido nos ofícios-circulares anuais da Superintendência de Relações com Empresas - SEP, que estabelecem as orientações gerais a serem observadas por todas as companhias abertas, cf. item 6.1.1 do Ofício-Circular SEP 02/2015, item 7.1.1 do Ofício-Circular SEP 02/2016, item 7.1.1 do Ofício-Circular SEP 01/2017, item 7.1.1 do OfícioCircular SEP 02/2018 e item 7.1.1 do Ofício-Circular SEP 03/2019.

93 Para exame extensivo sobre a venda de votos, cf. SCIMEMI, 2003. Esclarece-se, desde já, que este estudo diz respeito ao fenômeno dos novos mecanismos de negociação de votos (the new vote buying, conforme denominado por Hu e Black nos estudos ora analisados) e não se confunde com a negociação de votos, em que os votos são formalmente transferidos, ou negociados, por determinado acionista a terceiros.

94 Cf. Robert (2016, p. 78-85), que inicia pela identificação do fundamento da proibição: "a razão é a resistência natural à separação entre poder e propriedade, ou, de outra forma, entre retorno e risco", mas entende não haver restrições legais à cessão de voto no direito brasileiro.

95 Sobre o art. 177, § 2 , do Código Penal, cf. nota de rodapé à nota de texto do atualizador acerca da tipificação penal da "venda ou tráfico de voto" no art. $177, \S 2^{\circ}$, do Código Penal: "Em harmonia com o tratamento dado ao direito de voto no direito societário brasileiro, não seria outra a solução legislativa para o comércio de voto, na medida em que afeta a essência do conceito de sociedade". (COMPARATO; SALOMÃO FILHO, 2014, p. 173). Para uma proposta alternativa de interpretação do instituto, cf. Robert (2016, p. 82): "De tão direta, a norma passou a ser de difícil aplicação, sendo a interpretação do termo "negociar" como sendo a venda do voto ou operação similar uma sintetização que definitivamente não decorre da lei".

96 A respeito da dissociação entre o exercício do direito de voto e a titularidade das ações, vide Comparato 
jurídica nacional. ${ }^{97}$ Pouco se questiona quanto à efetiva existência de fundamentos jurídicos para a manutenção desse dogma, embora não se encontra na lei societária qualquer norma que a fundamente.

Há, pelo contrário, diversas hipóteses largamente admitidas em que a legitimação para o exercício dos direitos políticos se destaca da titularidade da ação, ${ }^{98}$ a exemplo de usufruto, ${ }^{99}$ penhor ${ }^{100}$ e alienação fiduciária de ações, ${ }^{101}$ inclusive com previsão legal nesse sentido. Da mesma forma, como tratado acima, as possíveis implicações da premissa da incindibilidade na celebração de acordos de acionistas sobre voto, representação de acionistas em assembleias e restrições à negociação de votos foram, ou vêm sendo, contornadas, em maior ou menor medida, conforme o caso, o que também indica a possibilidade de sua superação.

Tanto em razão da ausência de previsão legal que justifique sua manutenção, quando pelos diversos mecanismos previstos em lei que permitem a dissociação de direitos decorrentes da condição de acionista, propõe-se a superação do "dogma" da incindibilidade desses direitos. Dessa forma, hipóteses de dissociação de direitos decorrentes da condição de sócio, sejam tradicionais, sejam recentes, podem ser recepcionadas e acomodadas no sistema jurídico brasileiro, respeitados os limites legais, sem que haja violação de seus princípios e regras.

Nesse sentido, instrumentos financeiros que permitem o destacamento e negociação do conteúdo econômico decorrente da titularidade de ações, possibilitando os novos mecanismos de negociação de votos - por exemplo, o empréstimo de ações ${ }^{102}$ e a outorga de opções de compra e venda sobre as ações, ${ }^{103}$ bem como instrumentos

e Salomão Filho (2014, p. 173 e 176), que discordam do "dogma [d]a incessibilidade do direito de voto, desligado da titularidade das ações", afirmando que "essa dissociação entre a titularidade e a legitimação do veto fere a sensibilidade da doutrina jurídica brasileira, que vai repetindo tradicionalmente, só competir ao sócio ou ao acionista o exercício desse direito social. De nossa parte, não julgamos tal princípio logicamente inderrogável, nem vemos essa inderrogabilidade declarada na lei brasileira", em trecho constante do texto não atualizado.

${ }_{97}$ O anteprojeto da Lei das Sociedades por Ações, de acordo com seus autores, não abrigou a cessão do direito de voto, nem a cindibilidade dos direitos políticos e patrimoniais das ações, apesar de não admitir a afirmação de que o direito de voto estaria fora do comércio (LAMY FILHO; PEDREIRA, 1995, p. 154155). No entanto, não há vedação expressa na Lei das Sociedades por Ações que fundamenta esta afirmação, como reconhece Robert (2016, p. 83), ao tratar especificamente do direito de voto.

98 Cf., sobre a separação entre legitimação para exercício e titularidade do direito, Comparato e Salomão Filho (2014, p. 184 et seq.).

99 Sobre usufruto de ações, cf. Comparato (1978, p. 68 et seq.); Wald (1990, p. 5 et seq.); Leães (2004b, p. 1357 et seq.) e Guerreiro (1980a, p. 84 et seq.).

100 Cf., i.a., Ferri (1938) e Baggio e Rebecca (2005). No Brasil, ver Penteado (2008).

101 Vide, a respeito da alienação fiduciária, Moreira Alves (1973); Buzaid (1969) e Gomes (1972).

102 Sobre o aluguel de ações, cf. Robert (2015, p. 48); e Robert (2011). Interessante estudo que apresenta o mercado de aluguel de ações como um mercado de votos, em que o preço médio do voto, em si, é zero, ou tende a zero (CHRISTOFFERSEN; GÉCZY; MUSTO; REED, 2007).

103 Sobre as opções de compra e venda, especialmente sobre a estratégia de zero cost collar (compra de opção 
derivativos $^{104}$ - podem ser recepcionados como novos mecanismos que têm implicações semelhantes a estruturas já consolidadas e assimiladas pelo direito societário brasileiro, como usufruto, penhor, alienação fiduciária, e outras estruturas que desbalanceiam o poder político e os interesses econômicos dos acionistas.

Ressalta-se, a esse respeito, pelas eventuais confusões que podem ocorrer entre a cindibilidade e a divisibilidade dos direitos e obrigações ligados à titularidade de ações, que a indivisibilidade prevista na Lei das Sociedades por Ações ${ }^{105}$ tem por objetivo impedir a existência da figura dos acionistas fracionários, decorrente da divisão das ações em frações de unidades, ${ }^{106}$ com o objetivo de afastar qualquer obstáculo ao funcionamento interno das companhias. ${ }^{107} \mathrm{~A}$ regra não diz respeito, portanto, à dissociação entre os diversos direitos e obrigações decorrentes da condição de acionista, ${ }^{108}$ não podendo ser considerada um fundamento para o "dogma" da incindibilidade que se pretende superar.

\section{Os novos mecanismos de negociação de votos}

O mercado mundial de derivativos movimenta, atualmente, cerca de 700 (setecentos) trilhões de dólares, sendo o volume de instrumentos financeiros diretamente

de venda e venda de opção de compra sobre a mesma participação societária, de forma que os custos se igualam), cf. Hu e Black (2006a, p. 832); Tautges (2016, p. 58 et seq.). No Brasil, sobre opções de compra e venda de ações, ver, i.a., Souza Júnior (2002); Guerreiro (1980b, p. 226-229); Leães (2008, p. 101-115) e Sztajn (1997, p. 53-69).

104 Os instrumentos financeiros disponíveis permitem a transferência e alocação do retorno econômico das ações de determinada companhia de relativamente forma simples, já que permitem a indexação do retorno a virtualmente qualquer índice (ou composição sintética de índices). Sobre swaps, cf. Hu e Black (2006a, p. 837 et seq.). Cf., para uma análise de derivativos, como futuros (futures), contratos a termo (forwards), contratos de diferença (contracts for difference), Mittermeier (2014, p. 126 et seq.).

105 Ver art. 28: "A ação é indivisível em relação à companhia”. Carvalho de Mendonça (1963, p. 409-412) distingue com precisão a indivisibilidade perante a companhia e a divisibilidade entre os acionistas, afirmando expressamente que "em relação aos acionistas, a ação pode ser e é divisível", embora questione a justificativa para o fracionamento de ações, anteriormente admitido no direito brasileiro.

106 Cf. Carvalho de Mendonça (1963, p. 409-412) e Ferreira (1958, p. 1.045-1.048).

107 Ver Valverde (1941, p. 100-101).

108 Nesse sentido, vide Robert (2016, p. 82) ("É um dispositivo [artigo 28, da Lei das Sociedades por Ações], contudo, sabidamente voltado ao impedimento de fracionamento dos direitos do título, e não de destacamento entre direitos e o título"); Valverde (1941, p. 101) ("Não fere o princípio da indivisibilidade a possibilidade de serem as ações gravadas com cláusula de usufruto, pois que diferentes são os direitos que tocam ao usufrutuário e ao proprietário dela"); Pontes de Miranda (1984, p. 52) ("A ação não pode ser dividida; mas pode haver comunhão pro indiviso e comunhão pro diviso das ações ou da ação. Daí dizer o art. 13 do Decreto-lei n. 2.627: 'A ação é indivisivel em relação à sociedade'. Não entre acionista e terceiro"); Marcondes (1970, p. 216) (“O princípio cogita da ação-unidade, ou seja, uma ação"). Em sentido contrário, afirmando que o princípio da indivisibilidade compreende a incindibilidade, ver Lamy Filho e Pedreira (2009, p. 220-221). 
relacionados a títulos de participação societária (equity derivatives) superior a 3 (três) trilhões de dólares. ${ }^{109}$

Embora os contratos derivativos, na forma como são utilizados hoje, tenham sua origem na década de 1970, com a introdução do swap cambial, e desenvolvimento intenso na década de $1980,{ }^{110}$ com a estruturação de novos instrumentos, a consolidação deste mercado é recente. Nos anos 2000, diante do cenário de menores custos de transação em mercado e de maior possibilidade de divisão de riscos entre os agentes econômicos, ${ }^{111}$ possibilitou-se o uso corriqueiro dos instrumentos financeiros disponíveis. ${ }^{112}$

Esse novo contexto no mercado financeiro, possibilitou a negociação de derivativos que replicam os direitos patrimoniais (ou a propriedade econômica) decorrentes da titularidade de ações, destacando-os dos direitos políticos decorrentes das participações societárias correspondentes, ainda que formalmente tanto os direitos patrimoniais quanto os direitos políticos permaneçam com o acionista.

As novas formas dessa dissociação (decoupling, no original ${ }^{113}$ ) dos direitos patrimoniais e políticos decorrentes da condição de acionista são bastante numerosas e podem envolver instrumentos derivativos, operações de hedge, instrumentos híbridos e sintéticos, opções de compra e de venda, empréstimo (ou aluguel) de ações, ${ }^{114}$ e outros produtos financeiros que permitem a transferência dos riscos econômicos, sem a respectiva titularidade das participações societárias a eles relacionadas. ${ }^{115}$

Os novos mecanismos de negociação de votos (the new vote buying, no original) foram possibilitados por essa modernização dos instrumentos financeiros

109 Os dados foram obtidos na base online da ISDA (International Swaps and Derivatives Association). Disponível em: http://www2.isda.org/functional-areas/research/data-sources/. Acesso em: 28 ago. 2018.

110 Cf. Hu (1989, p. 334 et seq.). Sobre os contratos de swap, ver, i.a., Inzitari (2000, p. 665 et seq.).

111 Estes elementos são indicados por Allen e Gale (1994, p. 34 et seq.) como basilares para promoção da inovação financeira.

112 Ferrarini (2007, p. 629 et seq.) refere-se a esta disseminação dos instrumentos financeiros como " 'rivoluzioni' del derivati finanziari". Sobre a revolução dos derivativos, ver Schapiro (1993). Se, de um lado, os mercados de bolsa favorecem a uniformização e homogeneização de títulos, bem como a promoção de sua circulabilidade na maior medida possível, o mercado de balcão, por outro lado, permite a estruturação de instrumento com características únicas e não padronizadas, adequadas para determinada operação em especial, favorecendo a engenharia financeira e a inovação de instrumentos complexos. Apesar das diferenças entre os mercados, sobre a correlação entre o crescimento do volume de negociações de derivativos no mercado de balcão e em bolsa, vide Switzer e Shan (2014, p. 35 et seq.).

$113 \mathrm{O}$ termo decoupling é utilizado para indicar a separação de direitos e obrigações que fariam, em princípio, parte de um mesmo conjunto (ou "pacote"), cf. Hu (2015, p. 354).

114 O volume de operações de aluguel de ações, em agosto de 2016, foi de R \$ 68 bilhões, cerca de 3.400 vezes maior que os R \$ 20 milhões registrados em maio de 1996, momento em que a operação foi inicialmente permitida pelo Conselho Monetário Nacional, por meio da Resolução n. 2.268/1996, regulamentada pela Instrução CVM n. 249/1996. Disponível em: http://www.bmfbovespa.com.br/pt_br/servicos/emprestimode-ativos/volume-e-quantidade-de-operacoes.htm. Acesso em: 28 ago. 2018.

115 Tautges (2016, p. 43-72) resume os instrumentos que podem operar a dissociação dos direitos em dois grupos: derivativos (Derivaten) e operações de empréstimo de ações (Wertpapierdarlehen). 
disponíveis, bem como da disseminação de seu uso no mercado. ${ }^{116}$ Os referidos mecanismos correspondem a duas figuras, em particular: (i) voto vazio (empty voting); e (ii) propriedade oculta (conversível) (hidden (morphable) ownership). ${ }^{117}$

O cenário atual é de desenvolvimento e inovação de tais instrumentos, em linha com as perspectivas de progressivo crescimento do mercado financeiro. Em decorrência não só das novas tecnologias e instrumentos financeiros, mas também do grande crescimento no mercado de empréstimo de ativos e, ainda, da maior participação e envolvimento dos fundos de investimento nas sociedades investidas (principalmente fundos de hedge), ${ }^{118}$ as perspectivas são de haver cada vez mais oportunidades e facilidades de dissociação dos direitos patrimoniais e políticos decorrentes da titularidade de participações societárias aos acionistas que assim desejarem proceder.

Diante dessa nova realidade, apresentam-se, a seguir, os principais aspectos dos novos mecanismos de negociação de votos e das figuras que decorrem das novas oportunidades de desacoplamento dos direitos inerentes à posição de sócio, bem como as possíveis consequências dos novos mecanismos de negociação de votos, especialmente com relação aos fundamentos e premissas do direito societário. É de se ressaltar, ainda, que a dissociação de direitos decorrentes da condição de sócio, ora analisada, está acompanhada, ainda, de outras hipóteses de separação de direitos de outras naturezas que, em princípio, seriam concentrados em um mesmo titular (debt decoupling e hibrid decoupling).

\footnotetext{
116 Sobre a maior facilidade de dissociação entre os direitos patrimoniais e políticos decorrentes da condição de acionista, cf. Hu e Black (2006a, p. 815). Cf. Clottens (2012, p. 447 et seq.), afirmando que o empty voting não é um problema recente, ainda que sua concretização prática - e potencialmente em larga escala -, por outro lado, o seja.

117 As duas figuras são tratadas com mais detalhes nos capítulos IV.1.1 e IV.1.2, abaixo.

118 Os três fatores são apontados por Hu e Black, (2006a, p. 844-845). Sobre a atuação dos fundos de hedge no contexto das discussões da dissociação entre direitos patrimoniais e políticos, cf. Ringe (2013b) e Zanoni (2009). A atuação do hedge funds é especialmente relevante devido ao ativismo assumido pelos fundos de investimento nas sociedades investidas. Cf., i.a., Brav et al. (2008, p. 1.729 et seq.); e Kahan e Rock (2007, p. 1.021 et seq.); no Brasil, cf. Robert (2016, p. 181-186). Para breve análise atuação e apatia de investidores institucionais em determinadas circunstâncias, cf. Mittermeier (2014, p. 73-75). Interessante notar que, na regulação brasileira, os fundos de investimento em participação (FIPs) - que podem, desde a recente edição da Instrução CVM n. 578/2016, investir não só em companhias, abertas e fechadas, mas também em sociedades limitadas - devem participar do processo decisório das sociedades investidas, como requisito para realização de seus investimentos (art. $5^{\circ}$, caput, da referida instrução).
} 
4.1. Negociação de votos pelo reverso: a transferência da exposição econômica das ações

Os novos mecanismos de negociação de votos (the new vote buying, no original $^{119}$ ) correspondem às novas hipóteses de dissociação entre direitos patrimoniais e políticos decorrentes da condição de acionista, possibilitadas pelo desenvolvimento do mercado financeiro e disponibilização de novos produtos financeiros e derivativos, a custos relativamente baixos. Trata-se de fenômeno pouco regulado, do ponto de vista jurídico, e, em larga medida, não divulgado, por não ser atingido pela maioria das regras atuais de divulgação de informação. ${ }^{120}$

A principal inovação nesses novos mecanismos de negociação de votos não é a separação dos direitos patrimoniais e políticos decorrentes da condição de acionista em si, já bastante conhecida e consolidada em hipóteses tradicionais de separação (alienação fiduciária, penhor, usufruto, estrutura dual de classes, etc.). Diferentemente das hipóteses tradicionais de dissociação, não se trata de estruturas das quais deriva a separação formal entre direitos patrimoniais e políticos, que passam a integrar o patrimônio de dois sujeitos de direito distintos.

Pelo contrário, não há a separação entre a titularidade dos direitos decorrentes da ação emitida pela companhia, do ponto de vista jurídico. O mesmo acionista permanece titular tanto dos direitos políticos quanto dos direitos patrimoniais decorrentes de seu estado de sócio.

Não há a transferência dos direitos de voto, ou demais direitos políticos decorrentes da titularidade das ações, a terceiros. ${ }^{121}$ Nesses casos, o acionista registrado nos livros da companhia é aquele que permanece titular dos direitos políticos vinculados às ações que detém e pode exercê-los perante a companhia e seus órgãos sociais.

119 A designação do fenômeno como "the new vote buying" ou "decoupling", conforme mencionado acima, é de Hu e Black, pioneiros no tratamento sistemático conferido ao assunto. Não se pode deixar de notar, contudo, a existência de discussões preliminares sobre o assunto, como aquelas de Martin e Partnoy (2005, p. 775 et seq.), ao tratar de ações oneradas (no original, encumbered shares) e de Manne (1964, p. 1.427-1.445), que trata de inter-relação entre os direitos políticos e a exposição econômica relacionados à titularidade de ações.

120 Cf. Hu e Black (2006a, p. 818).

121 Nesse sentido, cf. a afirmação de Robert (2016, p. 57), ao tratar do fenômeno "não se trata - e aí está a questão mais interessante - de venda do voto ou de transferência do direito de voto. Também não se trata de situações de eventual irregularidade no exercício do direito de voto objetivando algum ganho que decorra da própria participação na sociedade, com o custo do prejuízo de outros acionistas da mesma sociedade". No mesmo sentido, reconhecendo que, nos exemplos de empty voting e hidden ownership analisados não se opera "un 'acquisto' del voto in senso tecnico", cf. Ferrarini (2007, p. 629 et seq.). Igualmente, tratando da jurisprudência estadunidense sobre operações de alienação de voto, caracterizadas pela presença de dois polos definidos (vendedor do voto e comprador do voto), os quais não se encontram presentes nas hipóteses do fenômeno de "new vote buying", cf. Hu e Black (2006a, p. 818 e 862). 
Não se trata, portanto, da controvertida operação de negociação de votos em si, apesar de o nome conferido ao fenômeno poder induzir inadvertidamente a essa conclusão. É, na verdade, o reverso da negociação de votos: transfere-se e se negocia a exposição econômica relacionada à titularidade das ações, prática cuja licitude não se questiona. A rigor, sequer é necessário que um acionista formalmente registrado nos livros sociais tome parte na negociação sobre a exposição econômica de determinada companhia: terceiros podem negociar entre si retornos indexados nos resultados de determinada companhia, por meio de instrumentos derivativos.

O acionista que é formalmente titular das ações também é aquele que faz jus à repartição dos lucros provenientes do exercício das atividades sociais perante a companhia, sendo ele o legitimado a receber os proventos ${ }^{122}$ distribuídos pela companhia e a partilhar os lucros sociais sob as formas possíveis. Embora seja o titular formal desse retorno perante a companhia, os contratos celebrados com terceiros fazem com que, economicamente, não seja a parte que suporta, ao final, esse retorno, o qual foi transferido aos terceiros em questão.

As novas estruturas de dissociação, na verdade, operam no âmbito da exposição econômica decorrente da titularidade de ações. A exposição econômica decorrente da titularidade de ações é transferida pelo acionista a terceiros, que passam a, indiretamente, partilhar o risco econômico das atividades da sociedade emissora, seja em razão da flutuação do preço de cotação das ações, atribuição de proventos, e outras formas de divisão do lucro social. O acionista, de outro lado, recebe, em seu lugar, um retorno fixo ou variável relacionado a determinado índice de mercado, inclusive outras ações, que venha a ser acordado com o terceiro.

Em decorrência da contratação de instrumentos financeiros ou realização de operações equivalentes, o acionista, formalmente permanece titular dos direitos patrimoniais respectivos. No entanto, deixa de suportar o retorno econômico relacionado às ações que detém, por tê-lo transferido a terceiros, em troca de determinado retorno, fixo ou variável.

Com a transferência da exposição econômica pelo acionista, opera-se, por consequência, a dissociação entre os direitos patrimoniais e políticos decorrentes do estado de sócio, ainda que formalmente não haja a alteração da titularidade formal dos direitos patrimoniais decorrentes da condição de sócio. ${ }^{123}$

\footnotetext{
122 O termo "proventos" corresponde a direitos atribuídos aos titulares de ações, a exemplo de "direitos de preferência para subscrição de ações, bônus de subscrição ou debêntures conversíveis em ações, dividendos, juros sobre capital próprio, rendimentos, prêmios, amortizações, reembolsos, resgate, bonificações, grupamentos, desdobramentos, entre outros" (cf. capítulo 1 (definições) do Regulamento para Listagem de Emissores e Admissão à Negociação de Valores Mobiliários da B3 - Brasil, Bolsa, Balcão).

123 A operação se divide em duas etapas: em primeiro lugar, a aquisição das participações societárias; e,
} 
O fenômeno é hoje uma realidade presente, havendo mais de uma centena de exemplos já conhecidos em todo o mundo, em geral envolvendo disputas pelo controle societário. ${ }^{124} \mathrm{~A}$ realidade, inclusive, não é desconhecida no mercado brasileiro. ${ }^{125} \mathrm{O}$ número de casos conhecidos, no entanto, pode representar uma estimativa subestimada do volume real de ocorrência de operações que se enquadrem nos novos mecanismos de negociação de votos, uma vez que ainda não há um tratamento sistemático quanto à obrigação de divulgar informações sobre operações dessa natureza. ${ }^{126}$

O fenômeno contempla duas principais figuras, voto vazio (empty voting) e propriedade oculta (conversível) (hidden (morphable) ownership), que tipicamente decorrem da dissociação dos direitos patrimoniais e políticos dos acionistas e, embora relacionadas entre si, possuem particularidades que importam análise e tratamento diferenciados de cada uma delas.

\subsubsection{Voto vazio (Empty Voting)}

Empty voting é a primeira figura dos novos mecanismos de compra de votos e diz respeito à hipótese em que os direitos políticos de determinado acionista excedem sua propriedade econômica (ou interesse econômico) sobre as ações da companhia de que participa. ${ }^{127}$ Outras possíveis denominações e traduções do mecanismo são "voto

em seguida, a transferência (no original, shift) da correspondente exposição econômica (ou propriedade econômica) (HU; BLACK, 2008a, p. 641).

124 Os novos mecanismos de negociação de votos não se limitem a disputas pelo controle societário, como demonstra o caso Telus, tratado anteriormente neste artigo, que diz respeito à disputa sobre a conversão de classes de ações.

125 Ver Revista Capital Aberto, n. 98, de outubro de 2011, que reporta discussões sobre a matéria na Europa ("Regulador europeu estuda coibir 'voto vazio"). Cf. também reportagens da Revista Capital Aberto, n. 43, 109 e 110, de março de 2007, setembro de 2012 e outubro de 2012, intituladas "Riscos do Aluguel", "Dono Escondido" e "Acionistas Mascarados", que tratam do aluguel de ações, do caso envolvendo a Metalfrio Solutions S.A. e total return swaps em geral, respectivamente. Cf., ainda, reportagem do Estadão de 17 de julho de 2015 ("Questionamento sobre práticas de governança da Gerdau volta à tona"), em relação à Gerdau S.A. Sobre o caso GVT Holding S.A. e Vivendi S.A., cf. Robert (2016, p. 62-63). Ver, ainda, voto da diretora da CVM Ana Dolores Moura Carneiro de Novaes no caso Azul (processo CVM n. RJ 2013/5993, j. 31.01.2014), em que enunciou a existência dos fenômenos de empty voting e hidden ownership.

126 Cf. Hu e Black (2008b, p. 16 e 36-42). Os autores mencionam, inclusive, que os casos identificados podem representar apenas a "ponta de um iceberg", metáfora para representar o volume de casos que podem não se ter tornado públicos.

127 Cf. Hu e Black (2007, p. 2). 
vuoto", 128 "Stimmrecht ohne Beteiligungsinteresse", 129 "risikoentleertes Abstimmen", 130 "risikoentleerte Stimmrechte", 131 "vote vide", ${ }^{132}$ "voto vacio""133 e "shell voting". 134

A exposição econômica sobre a companhia pode decorrer tanto da própria titularidade das ações por ela emitidas, como tradicionalmente se considera, quanto e neste ponto se encontra a inovação possibilitada pelo desenvolvimento do mercado financeiro - por meio de ativos acoplados a tais ações (no original, coupled assets). ${ }^{135}$ Os ativos acoplados podem ser os mais diversos, incluindo derivativos (opções, contratos de futuro, swaps, etc.), direitos contratuais decorrentes de operações de empréstimo de ações, ou, ainda, outros instrumentos financeiros, relacionados, direta ou indiretamente, aos direitos patrimoniais decorrentes das ações. ${ }^{136}$

Em geral, esses dois elementos (direitos patrimoniais decorrentes da titularidade das ações e exposição econômica decorrente de ativos acoplados) são suficientes para adequada identificação da exposição econômica do acionista.

Há, no entanto, hipóteses em que um terceiro elemento também deve ser considerado: ativos relacionados, de alguma forma, aos resultados da companhia, mas que não são emitidos pela companhia em questão, nem que estão acoplados ou indexados nas ações por ela emitidas. ${ }^{137}$ Trata-se, por exemplo, de ativos relacionados emitidos por contrapartes em operações, concorrentes ou partes relacionadas, ou, ainda, ativos a eles acoplados. Os ativos relacionados têm especial aplicação em operações de fusões e aquisições, uma vez que a participação ou exposição a contrapartes permite, em certa medida, a manipulação das operações e dos incentivos envolvidos em sua aprovação pelos órgãos sociais e na avaliação das empresas envolvidas. ${ }^{138}$

A partir da cumulação dos três elementos indicados acima (exposição econômica decorrente da titularidade das ações, de ativos acoplados e de ativos relacionados), pode-se, então, identificar a exposição econômica global do acionista ou de terceiros que não sejam formalmente acionistas de determinada companhia. ${ }^{139}$

\footnotetext{
128 Cf. Luca (2010, p. 314). Ver, ainda, sobre o “'svuotamento' del voto”, Ferrarini (2007, p. 629 et seq.).

129 Cf. Ostler (2010).

130 Cf. Kumpan e Mittermeier (2009, p. 404 et seq.).

131 Cf. Kumpan e Mittermeier (2009, p. 404 et seq.) e Mittermeier (2014).

132 Cf. Le Nabasque (2010), Berdou (2011) e Clerc (2008).

133 Cf. Munõz Pérez (2013, p. 146) e Díaz Ruiz (2013, p. 3).

134 Cf. Thompson (2006, p. 33) e Ringe (2013b, p. 1.033 e 1.073).

135 Cf. Hu e Black (2006a, p. 824).

136 Cf. Hu e Black, (2008a, p. 638).

137 Cf. Hu e Black (2008a, p. 637); Hu e Black (2006a, p. 825) e Mittermeier (2014, p. 149 et seq.).

138 Vide Hu e Black (2006a, p. 843).

$139 \mathrm{Hu}$ e Black (2006a, p. 825) diferenciam o interesse global do acionista, definido nos termos acima, e interesse econômico líquido, calculado apenas pelos direitos decorrentes da propriedade em si das ações e dos ativos acoplados, sem considerar os ativos relacionados.
} 
A exposição econômica do acionista pode ser maior ou menor que os direitos políticos por ele detidos, em decorrência da titularidade formal das ações. Se os direitos políticos excederem os interesses econômicos, tem-se a figura do voto vazio (empty voting). Analisando-se o mesmo fenômeno sob uma segunda perspectiva, temse as denominadas ações economicamente oneradas (encumbered shares, no original ${ }^{140}$ ), hipótese em que o titular das ações deixa de ter incentivos tidos como naturalmente decorrentes da propriedade de tais ações.

A exposição econômica do acionista em relação à companhia, em termos absolutos - ou seja, independentemente da comparação com os direitos políticos por ele detidos -, pode, ainda, ser positiva (positive risk-decoupling), neutra ou negativa (negative risk-decoupling). ${ }^{141}$

Neste último caso, tem-se a hipótese do negative voting, ${ }^{142}$ na qual os interesses do acionista estão em tal medida desencontrados com sua posição jurídica de sócio e foram em tal medida esvaziados, que este se beneficia da redução de valor da companhia. ${ }^{143}$ A hipótese de negative voting é, de fato, aquela que mais pode causar descompassos no funcionamento interno da companhia, pois subverte completamente as premissas do direito societário e composição de interesses dos acionistas interna corporis. ${ }^{144}$

O terceiro que adquire a posição econômica de acionista em uma companhia, para o qual foi transferida a exposição econômica inicialmente suportada pelos acionistas formalmente registrados nos livros da companhia, por sua vez, pode ser considerado como titular de ações sintéticas virtualmente emitidas pela companhia (synthetic shares, no original). ${ }^{145}$ Isso porque passa a suportar a exposição econômica decorrente da titularidade de ações, como se detivesse efetivamente tais ações, ainda que formalmente não seja registrado como acionista da companhia. Não há qualquer alteração no número

140 O termo "encumbered shares" é de Martin e Partnoy (2005, p. 780). O termo foi usado anteriormente à sistematização da figura do voto vazio (empty voting) e propriedade oculta (conversível) (hidden (morphable) ownership), mas diz respeito ao mesmo fenômeno de dissociação entre direitos políticos e patrimoniais atrelados à titularidade de ações.

141 A classificação de positive risk-decoupling e negative risk-decoupling é de Ringe (2016, especialmente p. 27 et seq.).

142 Sobre a situação de negative voting, cf., no Brasil, Robert (2016, p. 56-59). Na literatura estrangeira, cf. Cohen (2008) e Mittermeier (2014, p. 183-184).

143 Martin e Partnoy (2005, p. 809-810) denominam de voting arbitrage as hipóteses em que acionistas com disparidade de incentivos em relação ao que naturalmente se esperaria de sua posição de proprietários residuais da companhia votam em benefício de seus próprios interesses e em detrimento dos demais acionistas e da companhia. Os autores mencionam, ainda, que os acionistas em questão podem votar de forma sub-ótima, ao procurarem promover seus interesses.

144 Cf. Cohen (2008, p. 240 e 242), que afirma "negative voting has the most potential for wealth destruction of all new forms of vote buying"; " "negative voting is the worst form of new vote buying".

145 Ver Martin e Partnoy (2005, p. 779). 
de ações efetivamente emitidas, no capital social, ou quaisquer outros elementos formais da estrutura societária da companhia, mas apenas a transferência da posição econômica de acionista para terceiros, estranhos à composição formal da companhia.

\subsubsection{Propriedade oculta (conversível) (Hidden (morphable) ownership)}

A segunda figura dentre os novos mecanismos de negociação de votos é a propriedade oculta (conversível) (hidden (morphable) ownership), que significa a propriedade econômica oculta das ações, não captada pelas regras de divulgação de informações aplicáveis. Um terceiro suporta a exposição econômica relacionada a ações, sem sua titularidade formal, e, por essa razão, não se dá a publicidade equivalente àquela que seria aplicável caso detivesse a titularidade formal dessas mesmas ações. A figura é, igualmente, denominada "proprietà nascosta", ${ }_{146}$ "Quasi-Eigentümerstellung"147 e "propiedad oculta". ${ }^{148}$

A existência de acionistas que são formalmente titulares de ações, mas permanecem vinculados a terceiros, proprietários de fato das ações, estes últimos ocultos, não é fenômeno recente. A existência de acionistas fiduciários (ou "prestanomes"149) foi reportada já no início do século XX e, da mesma forma, a preocupação quanto ao exercício de direitos societários de forma não revelada já estava presente quando da elaboração do projeto de Lei das Sociedades por Ações. ${ }^{150}$ A inovação na figura da propriedade oculta (conversível), como já se apresentou acima, é a utilização de instrumentos financeiros recentes, que permitem a transferência da exposição econômica relacionada à titularidade das ações, com essa finalidade.

A figura pode, a rigor, ser dividida entre propriedade oculta (hidden ownership) e propriedade oculta conversível (hidden morphable ownership). Em ambos os casos, quem suporta a exposição econômica permanece não revelado à companhia, aos acionistas ou a terceiros. A diferença entre as espécies encontra-se na faculdade de proprietário oculto adquirir e exercer, formal ou informalmente, os diretos políticos decorrentes da titularidade das ações emitidas pela companhia, identificada apenas na

\footnotetext{
146 Cf. Luca (2010, p. 319). Ver, ainda, sobre o esvaziamento do direito de voto (" svuotamento'del voto", no original), Ferrarini (2007, p. 631).

147 Cf. Tautges (2016, p. 113).

148 Cf. Muñoz Pérez, (2013, p. 23).

149 Cf. Vivante (1903, p. 167 et seq.). O autor também condenou a denominação pejorativa de testas de ferro (no original, "testas di legno") a tais acionistas.

150 Lamy Filho e Bulhões Pedreira (1995, p. 164), ao tratarem das ações ao portador e justificarem a ausência de direito de voto conferida aos seus titulares (conforme o art. 112, caput, da Lei das Sociedades por Ações), afirmam: "a ação ao portador era o instrumento de controle oculto das sociedades brasileiras".
} 
figura da propriedade oculta conversível (hidden morphable ownership). ${ }^{151}$ Ou seja, tratase da possibilidade de adquirir o exercício, de direito ou de fato, de direitos políticos na companhia por terceiro que não detém a titularidade formal de suas ações. ${ }^{152}$

A ideia fundamental do mecanismo é a manutenção das ações sob a titularidade formal de pessoas relacionadas, que permitam o exercício informal dos direitos políticos decorrentes da posição de acionista e, em especial, o acesso ao direito de voto, pelo proprietário oculto, se e quando este último entender necessário. ${ }^{153}$ Os instrumentos utilizados com essa finalidade são os mesmos daqueles utilizados na figura do voto vazio, ${ }^{154}$ podendo ser utilizados swaps, futuros, opções, alienação de ações com a contratação de hedge por parte do adquirente, aluguel de ações ou outros instrumentos financeiros.

Trata-se de uma forma de estacionamento de ações (soft parking, no original), em que o proprietário oculto (parker) mantém suas ações "estacionadas" com terceiros, os acionistas, do ponto de vista formal, (parkees) geralmente instituições intermediárias do mercado de capitais (por exemplo, corretoras e distribuidoras de valores mobiliários e instituições financeiras). Os parkees assumirão a posição de titulares formais das ações, mantendo-se oculta, perante a companhia, demais acionistas e terceiros, a identidade do parker. ${ }^{155}$

A qualificação de soft parking, por sua vez, se dá em oposição a operações de hard parking de ações ou outros valores mobiliários, em que há a formalização contratual do exercício dos direitos de voto, da alocação do retorno atrelado aos direitos patrimoniais, ou, ainda, há a transferência formal das ações entre as partes. ${ }^{156}$

Como os acionistas formalmente titulares das ações não têm qualquer exposição econômica na companhia, podem, portanto, seguir quaisquer instruções de voto encaminhadas pelos proprietários ocultos sem que tenham seus interesses econômicos

151 Cf. Hu e Black (2006a, p. 815-816).

152 Nesse sentido, cf. De Nardis e Tonello (2010), sobre a hidden ownership decorrente de esquemas de equity swaps: "this hidden ownership scheme allows the undisclosed retention of de facto voting rights exercisable at the investor's discretion". O reverso da aquisição do exercício de fato (morphing, no original) é a transferência do exercício (shedding, no original), cf. Hu e Black (2006a, p. 841).

153 Hu e Black (2008a, p. 644, 727 et seq.); Hu e Black (2008b, p. 2); e Hu (2015, p. 359).

154 Cf. Hu e Black (2008a, p. 646 et seq.) e Hu e Black (2008b, p. 11).

155 Sobre parking shares, cf. Hazen (2005) (de acordo com o autor, “"parking', [...] consists of hiding the true identity of a security's owner"); Loss e Seligman (2003, p. 611) e Lowenfels e Bromberg (1991).

156 Cf. Hu e Black (2008a, p. 644-645, 727 et seq.). Os autores apresentam, ainda, benefícios do mecanismo de soft parking caso seja utilizado pela própria companhia, em relação a mecanismos como a recompra das ações com a companhia (uma vez que, nesta hipótese, as ações em tesouraria não têm seu direito de voto e, portanto, não se podem exercer os direitos políticos delas decorrentes) e a mera manutenção das ações com terceiros (os denominados "escudeiros brancos" (white squires), no jargão financeiro), sem o esquema de organização dos riscos econômicos a elas atrelados (já que, nesse caso, os custos de transação com este terceiro são mais elevados, da mesma forma que o alinhamento entre as partes é mais instável). 
afetados. Eles irão, informalmente, exercer o direito de voto no sentido indicado pelos proprietários ocultos (mantêm-se as ações "em mãos amigas" ${ }^{157}$ ), em benefício da manutenção de suas relações comerciais em bases saudáveis e garantia de sua boa reputação em mercado. ${ }^{158}$

Embora os direitos de voto dos proprietários ocultos sejam implícitos e informais, as estruturas desenhadas para promovê-los, em geral, não apresentam outra finalidade além da própria não divulgação da identidade do proprietário oculto, com a manutenção da possibilidade do exercício, de fato, de tais direitos nas esferas societárias da companhia. ${ }^{159}$

A não divulgação da identidade do proprietário oculto, por sua vez, pode ser usada para evitar a aplicação de determinadas regras ou restrições (por exemplo, a realização de ofertas públicas de aquisição por aumento de participação, a limitação à participação estrangeira no capital social de sociedades atuantes em determinados mercados, a limitação à negociação de ações em períodos de restrição, entre outros), ou no contexto de atuação em deliberações societárias, sem que o responsável seja reconhecido pelo mercado e pela companhia, por razões estratégicas.

\subsection{Possíveis consequências do fenômeno}

Em razão dos novos mecanismos de negociação de votos, um dos pressupostos organizativos do direito societário - a vinculação e a correlação entre direitos políticos e direitos patrimoniais decorrentes do status especial de sócio - passa a ser ainda mais facilmente desconstruído na realidade atual das companhias. ${ }^{160}$

Deixam, assim, de ser necessariamente confiados o paradigma de correspondência e proporcionalidade entre direitos de voto e participação acionária; a premissa de one share, one vote; ou, ainda, a conclusão de que os acionistas detêm o poder decisório por serem os proprietários residuais da companhia. ${ }^{161}$

157 Cf. Hu e Black (2008a, p. 638).

158 Sobre a existência de pactos parassociais não divulgados e não transparentes ao mercado, cf. Legnani (2012).

159 A finalidade é ainda mais evidente se os instrumentos forem utilizados pela própria companhia, ou sua administração, que pode assumir a condição de titular de direitos de voto ocultos que, de outra forma, por se tratar de ações em tesouraria, não seriam exercíveis (cf. art. 30, $\S 4^{\circ}$ da Lei das Sociedades por Ações). Hu e Black mencionam que companhia pode ser vista como uma proprietária oculta de si própria, com direitos de voto exercíveis informalmente (HU; BLACK, 2008a, p. 643) - ainda que tais direitos de voto não possam ser formalmente adquiridos pela companhia, já que ações em tesouraria são destituídas de direitos de voto.

160 Como observa Robert (2016, p. 57), ao analisar dois casos reconhecidos de dissociação entre os direitos políticos e econômicos, que geraram interesses negativos dos acionistas em relação às companhias de que participam: "é notável a desintegração do vínculo, tão caro ao direito societário, entre o poder político contido na ação e a substância econômica subjacente à mesma ação".

161 Cf. Hu e Black (2006a). Sobre a questão da propriedade residual e alocação dos direitos de voto nos 
Diante da nova realidade, passa a ser necessária a reavaliação da forma como o funcionamento interno e externo das sociedades e a interação entre os diversos agentes envolvidos é captada e tratada pelo Direito. Revisitam-se, dessa forma, as discussões quanto à adequação do enfoque existente atualmente sobre sociedades e modelos de governança, que se concentra na primazia dos acionistas ${ }^{162}$ e pressupõe o vínculo entre todos os direitos que decorrem da condição de acionista. ${ }^{163}$

A maior facilidade na separação, compartilhamento e distribuição de riscos entre diversos participantes do mercado permite, igualmente, que se questione a alocação dos direitos de voto e dos riscos (e retornos econômicos) relacionados às atividades sociais, em última instância, apenas nos acionistas. A divisão, agrupamento e compartilhamento do risco econômico com outros participantes do mercado que não apenas os acionistas podem até mesmo pôr em xeque a premissa de que os acionistas são aqueles que suportam os riscos residuais da atividade empresarial com menor custo. ${ }^{164}$

Não se pode deixar de notar, ainda, os efeitos tanto positivos, quanto negativos, para o funcionamento das sociedades anônimas que podem resultar da dissociação desses direitos e sua dispersão entre diversos agentes.

A dissociação dos direitos decorrentes da posição de acionista pode ser vista de forma positiva se considerados, dentre outros, a maior facilidade de transferência

acionistas, tendo em vista a possibilidade de separação entre direitos patrimoniais e políticos, bem como a respeito da quebra de homogeneidade de incentivos, cf. Martin e Partnoy (2005, p. 792). Cf., para discussão da homogeneidade de interesses dos acionistas, tendo em vista a maximização dos resultados (Vermögensmaximierung), e consequências da dissociação entre os direitos políticos e patrimoniais dos acionistas, Mittermeier (2014, p. 78-82) e Tautges (2016, p. 143-144). Robert (2016, p. 61) distingue duas premissas que são desconstruídas pela constatação da realidade dos novos mecanismos de negociação de votos: a primeira, de que os acionistas sempre votem tendo em vista a valorização de suas ações (diante do negative voting, que faz com que o acionista tenha interesse no mau desempenho das atividades da companhia); e a segunda, de que os acionistas sempre usem todos os meios para proteção de seus interesses econômicos (diante do empty voting e da hidden ownership, uma vez que o acionista é destituído da exposição econômica que justificaria sua atuação).

162 Sobre a preponderância do modelo centrado nos acionistas (shareholder centered), cf. estudo de Hansmann e Kraakman (2000), e sua reafirmação posterior (HANSMANN; KRAAKMAN, 2012). A nova realidade do mercado pode dar novos rumos ao direito societário e às questões por ele endereçadas, bem como leva ao questionamento da aplicabilidade da conclusão quanto ao "fim da história do direito societário".

163 A percepção da sociedade como nexo de contratos, que não privilegia qualquer dos envolvidos em detrimento dos demais e, portanto, não garantir ao acionista a posição especial de "dono" da sociedade pode se mostrar adequada para explicar, sem resistências decorrentes de premissas subjetivas, que a repartição de direitos entre diversos participantes do mercado pode ser eficiente do ponto de vista econômico, em relação à alocação ótima de recursos (nesse caso, direitos políticos e direitos patrimoniais). Cf., para análise das sociedades como nexo de contratos, Coase (1937); Jensen e Meckling (1976) e Eisenberg (1999, p. 819 et seq.). Apresentando críticas à primazia dos interesses dos acionistas, cf., i.a., Barry, Hatfield e Kominers (2013).

164 Nesse sentido, para abordagem sobre a eficiência no compartilhamento de riscos Gilson e Whitehead (2008, p. 231 et seq.). Sobre a eficiência no campo jurídico, cf. Stigler (1992, p. 455-468). A respeito de modelos de eficiência, cf. Sztajn (2005, p. 78 et seq.). 
da exposição econômica decorrente da titularidade de ações, a possibilidade de alocação de riscos em agentes que os suportam com menores custos ou de direitos com aqueles que os exerçam de forma mais adequada e com maiores ganhos. ${ }^{165}$

De outro lado, podem ser causadas distorções no mercado de controle societário, ${ }^{166}$ em decorrência da possibilidade de entrincheiramento dos administradores, mediante a realização de operações que permitam aquisição de ações pela própria companhia emissora, controladas por seus administradores, que as utilizam em proteção contra a aquisição hostil de controle. ${ }^{167}$ Outro possível efeito negativo é a eventual divergência dos interesses - refletindo-se no exercício do direito de voto e demais direitos políticos - entre os acionistas que transferiram sua exposição econômica em determinada companhia, de um lado, frente aos demais acionistas e a companhia em questão, de outro lado. ${ }^{168}$

Embora não sejam, em si, negativos, os novos mecanismos de negociação de votos são, na grande maioria dos casos de que se tem notícia, usados para atender aos interesses dos próprios envolvidos (empty voters ou hidden owners) e não no interesse da companhia, nem do conjunto de seus acionistas.

Em geral, nos casos noticiados, os instrumentos derivativos, empréstimos de ações e demais estruturas que permitem a dissociação dos direitos decorrentes da condição de acionista são usados de forma a atingir objetivos não permitidos pela legislação ou regulação aplicável, ou a se furtar ao cumprimento de determinadas normas

165 Um dos argumentos pela eficiência do modelo de circulação de direitos e riscos decorrentes da posição de sócio é que, dessa forma, eles podem ser alocados com os sujeitos que estejam mais preparados para exercêlos ou suportá-los (HU; BLACK, 2008b, p. 14). Dessa forma, por exemplo, pessoas que detenham mais informações sobre a companhia podem adquirir votos de pessoas pouco informadas e exercê-los de forma mais eficiente, em benefício de todos os envolvidos (cf., nesse sentido, CHRISTOFFERSEN; GÉCZY; REED, 2007). No mesmo sentido, modelo para determinação da eficiência da atuação de empty voters foi proposto por Brav e Mathews (2011), que levam em conta o conhecimento privado de tal acionista em relação à sua condição peculiar. Ribstein e Kobayashi (2006, p. 23 et seq.), por sua vez, desenvolveram analisam os efeitos positivos decorrentes da negociação de informações não públicas, levando em conta o caso de empty voting envolvendo Perry Corp. e Mylan Laboratories.

166 Hu e Black mencionam que as práticas de dissociação dos direitos patrimoniais e políticos podem, no limite, levar à seleção adversa no mercado de controle societário, especialmente se observado um contexto de controle gerencial. Uma vez que terceiros não teriam a informação quanto à existência ou não de decoupling em determinada companhia, nem a razão entre propriedade econômica e direitos políticos dos insiders, o cenário de seleção adversa estaria perfeitamente caracterizado (HU; BLACK, 2006a, p. 858-859). Sobre seleção adversa, cf. Akerlof (1970, p. 488 et seq.).

167 As medidas contra a tomada hostil de controle por insiders são substancialmente mais presentes no mercado de capitais de outras jurisdições, como dos Estados Unidos, em relação ao mercado brasileiro. Cf., sobre o assunto, Bebchuk (2003). Ver, sobre o entrincheiramento de insiders, Bebchuk e Cohen (2005, p. 409 et seq.).

168 Cf. Martin e Partnoy (2005, p. 810). 
legais e regulatórias, especialmente aquelas relacionadas à divulgação de informações, ou que exigem a realização de ofertas públicas obrigatórias. ${ }^{169}$

$\mathrm{O}$ uso desses instrumentos para se evitar a divulgação de informações sensíveis tem especial aplicação em situações de disputa pelo controle societário, ou de disputas internas sobre determinada decisão relevante para a companhia, a ser tomada com a participação dos acionistas. A não divulgação de informações por potencial adquirente do controle e por determinados acionistas - nestes casos, para ocultar o aumento de sua participação societária na companhia -, ou pela própria companhia e seus administradores - em especial, para manter ações com terceiros que exerçam os direitos de voto de acordo com as instruções da administração -, possibilita que os demais participantes do mercado não tenham conhecimento de sua estratégia e, com isso, tenha uma vantagem na disputa societária em curso. ${ }^{170}$

Outro conjunto de normas cuja aplicação usualmente se busca evitar por meio da utilização de estruturas de voto vazio e propriedade oculta (conversível) é aquele que determina a realização de ofertas públicas de aquisição de ações obrigatórias, seja por aquisição de determinada participação societária relevante, transferência de controle ou, ainda, aumento de participação societária. Por meio dos novos mecanismos de negociação de votos, é possível atingir o resultado econômico de uma operação que implicaria a obrigatoriedade de realização de uma oferta pública, sem, contudo, ter o custo de sua efetiva realização. ${ }^{171}$

A consequência dos novos mecanismos de negociação de votos, embora represente uma alteração relevante no funcionamento das sociedades anônimas, não é, no entanto, necessariamente, negativa. A dissociação dos direitos decorrentes da posição de acionista, de igual forma, não deve ser sumariamente vedada, ${ }^{172}$ ainda que sua desvirtuação tenha impactos negativos. ${ }^{173}$

169 Sobre os mecanismos de evitar regras de divulgação de informações, tratando de regulatory arbitrage (ou seja, estrutura que se aproveita do "gap between the economic substance of a transaction and its legal or regulatory treatment, taking advantage of the legal system's intrinsically limited ability to attach formal labels that track the economics of transactions with sufficient precision"), cf. Fleischer (2010, p. 227 et seq.). Ver também Partnoy (1997, p. 211 et seq.). A não divulgação de informações particularmente sensíveis relacionadas às estruturas utilizadas nos novos mecanismos de negociação de votos pode, ainda, facilitar a ocorrência de práticas de insider trading e manipulação de mercado (HU; BLACK, 2008b, p. 27).

170 Cf. Hu e Black (2008a, p. 735-736). A estratégia pode, ainda, ser combinada com o mecanismo de wolf packs, referente à coordenação entre um grupo de investidores (em geral, fundos de investimento e outros investidores institucionais) que passam a atuar com o objetivo de aquisição do controle de determinada companhia. Ver, sobre wolf packs, Zetzsche (2009) e Lu (2016, p. 773 et seq.).

171 Cf. Hu e Black (2006a, p. 841).

172 Ver Hu e Black (2006a, p. 852), que, sobre os novos mecanismos de negociação de votos - empty voting e hidden (morphable) ownership -, afirmam categoricamente que "[are] not necessarily efficiency-reducing".

173 Cf. Vivante (1903, p. 168), que esclarece que a construção dos institutos jurídicos deve fundar-se em sua função essencial - seu escopo -, ainda que possam estar sujeitos a desvirtuamentos decorrentes de fraude ou 
Em verdade, a dissociação dos direitos decorrentes da posição do acionista é resultado de operações normais de mercado, amplamente difundidas atualmente, que envolvem instrumentos financeiros, hedge de riscos, empréstimos de ações e outros mecanismos dos quais, intencionalmente ou não, decorre a transferência da exposição econômica relacionada à titularidade das ações e, por consequência, a separação dos direitos de acionista. Não são operações, em si mesmas, ilegais ou irregulares. Os seus efeitos, positivos, neutros ou negativos, dependem de como, e para quais finalidades, ${ }^{174}$ tais operações são realizadas concretamente.

Os novos mecanismos de negociação de votos são, de fato, uma alteração relevante no funcionamento das sociedades, que não pode ser desconsiderada no momento da aplicação de normas jurídicas e da verificação da regularidade de operações societárias. A dissociação entre o risco empresarial, mediante a transferência da exposição econômica de ações, e os direitos políticos vinculados a estas mesmas ações pode ter resultados positivos, neutros ou negativos, conforme seja estruturada em cada caso e de acordo com as finalidades para as quais é realizada, a serem avaliadas em concreto.

\subsection{Dissociação de direitos. Equity decoupling. Debt e hybrid decoupling}

Os novos mecanismos de negociação de votos tratados anteriormente dizem respeito, em especial, à dissociação entre a exposição econômica e o direito de voto decorrente da titularidade de ações emitidas por companhias. A dissociação de direitos que, em princípio, estariam concentrados no acionista, no entanto, pode ser operada com relação a praticamente todos e quaisquer direitos e obrigações decorrentes da posição de acionista, políticos ou patrimoniais. Dessa forma, o voto vazio (empty voting) e a propriedade oculta (conversível) (hidden (morphable) ownership) não são as únicas figuras de dissociação de direitos e obrigações que podem ocorrer na prática, embora sejam as mais recorrentes. ${ }^{175}$

Além disso, os novos mecanismos de negociação de votos, relativos aos direitos e obrigações próprios dos acionistas, fazem parte da categoria de equity

abuso: "Ma la construzione giuridica di un istituto non si può fondare sovra gli abusi e de frodi cui porge occasione; la sua costruzione giuridica deve essere determinata dalla sua funzione essenziale, ciò̀ dal suo scopo, salvo poi a colpire le frodi quando sono provati".

174 Citam-se, por exemplo, dentre as finalidades reprováveis, que não poderiam ser perseguidas por meio de tais mecanismos: ( i) impedir o voto de terceiros; (ii) manter artificialmente o voto de ações, que, de outra forma, seriam destituídas desse direito, caso mantidas em tesouraria; (iii) evitar restrições impostas pelo direito concorrencial, inclusive quanto ao momento de efetivação da operação; (iv) evitar o cumprimento de obrigações contratuais e estatutárias, como poison pills; e (v) evitar o enquadramento da companhia em categoria com tratamento jurídico especial, como é o caso de holdings ou sociedades de investimento em determinadas jurisdições (HU; BLACK, 2006a, p. 842; HU; BLACK, 2008a, p. 639, 725-727).

175 Cf. Hu e Black (2008a, p. 721 et seq.). 
decoupling, ou seja, a dissociação de direitos e obrigações decorrentes da titularidade de participações societárias.

O equity decoupling, no entanto, não encerra as hipóteses cabíveis de dissociação de direitos e obrigações relacionada ao desenvolvimento das atividades empresariais. É igualmente possível a ocorrência de fenômenos semelhantes com relação a direitos e obrigações atrelados a títulos de dívida (debt decoupling) e a títulos híbridos (hybrid decoupling). ${ }^{176}$

Trata-se de situações que envolvem instrumentos de maior complexidade, por exemplo: instrumentos de reestruturação de dívidas, por meio de CLO (collateralized loan obligation) e CDO (collateralized debt obligation), ${ }^{177}$ derivativos sintéticos cujos ativos subjacentes podem ser tanto créditos quanto outros derivativos; swaps relacionados a créditos; recebíveis securitizados e outros créditos. ${ }^{178}$

A dissociação dos direitos de crédito e exposição econômica a eles relacionados também tem suas implicações sobre a governança da sociedade (a chamada debt governance $\left.{ }^{179}\right)$. Podem-se promover, nesse contexto, a assimetria de informação quanto à alocação da exposição econômica sobre o devedor e qual agente a suporta, em última instância, ou mesmo tornar mais difíceis e inflexíveis as renegociações de dívidas. Adicionalmente, o fenômeno pode gerar consequências negativas no exercício do direito de voto em situações de crise da empresa, nos fóruns adequados. ${ }^{180}$

As estruturas e os instrumentos de hybrid decoupling, ou dissociação híbrida, simultaneamente de direitos de crédito e participação societária, são, por sua vez, ainda mais complexas. A dissociação, neste caso, é operada por meio de operações que garantem a proteção de exposição atrelada a participações societárias por meio de instrumentos de dívida, e vice-versa. ${ }^{181}$ Podem ser usados com essa finalidade, por exemplo, EDS (equity default swaps) e EDO (equity default obligation, derivativos sintéticos cujos ativos subjacentes incluem EDS como parte do colateral). ${ }^{182}$

Este estudo trata dos novos mecanismos de negociação de votos e suas principais figuras, e, portanto, não se aprofundará nas demais formas de dissociação de

176 O tratamento sistemático foi conferido por Hu e Black em dois artigos conjuntos (2008a; 2008b) e um individual, de Hu (2015). Há, ainda, trabalhos contemporâneos de outros autores: Skeel e Partnoy (2007, p. 1.019 et seq.); Baird (2010, p. 648 et seq.) e Tautges (2016, p. 38-40). Não se tem notícia de discussões dessa natureza no Brasil.

177 Ver, para uma breve análise de CDOs e CLOs, seus riscos e valor, Duffie e Gârleanu (2001, p. 41 et seq.).

178 Hu e Black (2008a, p. 729).

$179 \mathrm{Hu}$ e Black (2008b, p. 2). Comentando caso ocorrido na crise de 2008, entre Goldman Sachs Gorup, Inc. e American International Group, Inc., cf. Hu (2009, p. A13).

$180 \mathrm{Cf} . \mathrm{Hu}(2015)$.

181 Cf. Das e Hanouna (2009) e Wu e Carr (2009).

182 Ver, sobre EDS, Medova e Smith (2004) e Jobst e Servigny (2005). 
direitos noticiadas acima. Cabe, contudo, a analogia com relação aos novos mecanismos de negociação de votos, em especial quanto à necessária alteração na forma de se observar o funcionamento das sociedades e as interações entre os agentes que participam da vida social.

\section{Notas finais}

As figuras que integram os denominados novos mecanismos de negociação de votos - voto vazio (empty voting) e propriedade oculta (conversível) (hidden (morphable) ownership) - são uma realidade no mercado de capitais em seu estágio de desenvolvimento atual. Seus impactos na dinâmica das companhias, portanto, não podem ser desconsiderados ou ignorados na interpretação e aplicação do direito. Passa a ser necessário, em verdade, buscar as respostas jurídicas adequadas para essas situações, diante das normas e princípios que informam o direito societário e o direito do mercado de capitais. ${ }^{183}$

As possíveis respostas, nesse sentido, compreendem tanto a recepção do uso legítimo dos novos mecanismos de negociação de votos, quanto a sanção de seu uso abusivo, caso se gerem prejuízos à companhia ou acionistas envolvidos, ou, ainda, ao mercado de capitais em geral. Outras respostas também passam pela alteração das normas legais e regulatórias aplicáveis, de forma a dar tratamento específico a essas novas figuras.

Nesse sentido, a divulgação de informações é o principal instrumento que pode ser utilizado para promover o bom funcionamento das estruturas societárias de companhias cujas ações têm os respectivos direitos dissociados e parcialmente transferidos de seus titulares formais. ${ }^{184} \mathrm{O}$ objetivo é tornar o mercado de capitais mais transparente e, portanto, mais previsível, estável e eficiente. ${ }^{185}$

Reconhecida a relevância da divulgação de informações, outro ponto a ser superado respeita ao modelo de divulgação de informações a ser aplicado, bem como

183 Não obstante o uso do termo "informar", não se deixa de notar a proposição de De Lucca (2009, p. 314315 , nota 7), quanto ao emprego do termo "enformar", em seu lugar. Ver também, sobre os princípios interpretativos e a modificação da interpretação das normas jurídicas no tempo, para captar situações não previstas (as ditas "lacunas de previsão"), Betti (1971, p. 118).

184 Uma das sugestões é a divulgação de todas as situações em que os direitos patrimoniais e políticos de determinado acionista se desbalancearem acima de determinada proporção, como sugerem Hu e Black (2008a, p. 692). Ver, ainda, Čulinović-Herc e Zubović (2015).

185 Cf., concluindo que as práticas de decoupling em mercados pouco transparentes podem torná-los imprevisíveis, instáveis e ineficientes, Barry, Hatfield e Kominers (2013, p. 201 et seq.). Ver, ainda, afirmando que "o mercado de capitais é fundamentalmente um mercado de informação", Cerezetti (2012, p. 206). Ver também, quanto aos benefícios do estabelecimento de regras de divulgação de informações no mercado (em particular, a uniformização das informações divulgadas e a redução dos custos de obtenção de informação pelos participantes do mercado), mesmo diante da irracionalidade verificada na realidade dos mercados, Georgakopoulos (2017, p. 69-70). 
as informações que se pretende obter e circular no mercado. Devem-se levar em conta não só a qualidade e a quantidade da informação, mas também o custo de produção das informações e os benefícios dela decorrentes. ${ }^{186}$

A divulgação de informações, por si só, é capaz de mitigar possíveis efeitos negativos decorrentes da propriedade (conversível) oculta (hidden (morphable) ownership). ${ }^{187}$ A partir do momento em que não há qualquer ocultamento ou informação não divulgada quanto à transferência dos direitos econômicos decorrentes da titularidade de ações, a propriedade econômica adquirida por terceiros simplesmente deixa de ser oculta.

As possíveis consequências negativas decorrentes do voto vazio (empty voting), por outro lado, são mais complexas e não são integralmente superadas pela divulgação de informações. Embora a divulgação de informações promova benefícios ao permitir que os acionistas e a companhia tenham conhecimento das hipóteses de desbalanceamento interno no exercício dos direitos decorrentes da posição de sócio e respectivo retorno patrimonial, ${ }^{188}$ não realinha os interesses dos acionistas, nem acopla novamente os direitos políticos e patrimoniais decorrentes da titularidade das ações.

Ou seja, ainda que haja a divulgação de informações, os direitos de voto permanecem dissociados e esvaziados de seu conteúdo econômico. A esse respeito, ressalta-se, novamente, que o desacoplamento dos direitos políticos e patrimoniais decorrentes da titularidade das ações, embora possa ser usado com finalidades fraudulentas - o que deve ser coibido -, não é necessariamente negativo e, portanto, não é desejável que seja sumariamente vedado pelo direito.

As possíveis repostas aos novos mecanismos de negociação de votos, em particular o voto vazio (empty voting), portanto, não se restringem à divulgação de informações, em especial porque os mecanismos internos das sociedades permanecem desbalanceados, da mesma forma que o sistema de incentivos e responsabilidades dos acionistas. ${ }^{189}$

186 A proposta de Hu e Black (2006a, p. 876; 2008a, p. 683) é a construção de um modelo de divulgação de informações único, aplicável a qualquer participante do mercado, incluindo tanto direitos patrimoniais ou políticos, quanto os interesses econômicos, positivos e negativos, sobre a companhia, dentre os quais aqueles decorrentes de ativos relacionados. Sobre modelos de divulgação de informação (modelo descritivo - no qual as informações são transmitidas por representações intermediárias entre a realidade e os observadores externos, as quais transcrevem a realidade objetiva -, modelo de transferência - a informação mimetiza a realidade objetiva e independe de interpretações e intervenções de intermediários - e modelo híbrido - a divulgação de informações se opera por modelos definidos pelo agente regulador, as quais são aplicáveis a qualquer regulado), defendendo a diversificação dos modelos adotados na prática, de forma a se promover a neutralidade da informação (information neutrality, no original), cf. Hu (2014) e Hu (2015).

187 Cf. Hu e Black (2006a, p. 820).

188 Cf. Briggs (2007).

189 Cf. a afirmação de Robert, que trata dos mecanismos como "desnaturadores do sistema de incentivos 
Uma das propostas adicionais à divulgação de informações é a limitação do exercício dos direitos de voto, com base na exposição econômica de cada acionista. A alternativa, no entanto, enfrenta dificuldades práticas quanto à mensuração da propriedade econômica, ${ }^{190}$ especialmente se houver ativos relacionados emitidos por terceiros que não a companhia. ${ }^{191} \mathrm{Da}$ mesma forma, conferir direitos de voto a terceiros que não são os titulares formais das ações, apenas pelo fato de deterem a propriedade econômica dos títulos, também esbarra em dificuldades operacionais de identificação de tais terceiros, envolvendo altos custos de transação e incertezas no funcionamento das companhias, ${ }^{192} \mathrm{o}$ que não é desejável.

Outra opção é regular (e restringir) a oferta e demanda dos instrumentos que possibilitam os novos mecanismos de negociação de votos, ou seja, os derivativos, empréstimos de ações, opções e outros instrumentos financeiros similares. Por meio de regulação, tais instrumentos podem-se tornar menos atrativos, ou mesmo ter seu volume limitado, ${ }^{193}$ de forma a restringir o interesse dos agentes econômicos em sua contratação e, com isso, reduzir sua disseminação no mercado.

Ambas as alternativas que excedem a divulgação de informações (alocação dos direitos de voto com base na exposição econômica do acionista e restrição dos instrumentos que possibilitam os novos mecanismos de negociação de votos), no entanto, parecem trazer dificuldades operacionais relevantes ou consequências indesejáveis, como

e responsabilização ordinários do direito societário" (ROBERT, 2016, p. 57). Ver, sobre o possível desbalanceamento provocado no sistema de responsabilização, Karmel (2010, p. 93 et seq.).

190 Cf. Hu e Black (2006a, p. 888). Martin e Partnoy (2005, p. 793), por sua vez, sugerem a restrição do direito de acionistas em short position ou que tenham contratado determinadas opções de compra e venda de ações, ou seja, que se protegeram dos riscos das ações de que sejam formalmente titulares. Nesse sentido, sobre a eficiência na alocação dos direitos de voto dos acionistas, cf. Barry, Hatfield e Kominers (2013).

191 Considerando-se, além dos direitos patrimoniais decorrentes diretamente da titularidade das ações, também os interesses decorrentes de ativos relacionados, pode-se chegar a situações em que o interesse econômico total dos acionistas e terceiros quanto à companhia seja superior ou inferior ao número total de ações. Nessa hipótese, caso os votos acompanhassem a propriedade econômica na mesma proporção, haveria mais votos do que o total de ações. Ver, a esse respeito, Martin e Partnoy (2005, p. 808). Cf., ainda, sobre o excesso de votos (overvoting) e arquitetura de votos, ainda que a discussão tenha especial aplicação no mercado dos Estados Unidos, devido à maneira como os direitos de voto são exercidos pelas instituições intermediárias e à existência de títulos desconhecidos do mercado brasileiro (por exemplo, as ações in street name, ou seja, ações que não são registradas em nome de seus efetivos titulares). (KAHAN; ROCK, 2007; DONALD, 2007).

192 Martin e Partnoy (2005, p. 807-809) afirmam que o fundamento para a alocação dos direitos de voto nos acionistas que estejam formalmente registrados nesta condição é a redução de custos de transação, e não a eficiência nessa alocação, ao contrário do que é usualmente afirmado. A existência de votos desconsiderados (disallowed votes, no original), por não refletirem o conteúdo econômico subjacente, poderia causar custos ainda superiores, inclusive à companhia, que deveria verificar a associação dos direitos patrimoniais e políticos relativos a cada ação em todos os eventos societários de deliberação e demais hipóteses de exercício dos direitos políticos dos acionistas (HU; BLACK, 2008a, p. 698-700).

193 Cf. Hu e Black (2008a, p. 709). 
a restrição do desenvolvimento do mercado financeiro e de capitais, que excedem os possíveis efeitos positivos de tais medidas. Por essa razão, não se propõe a adoção de qualquer dessas alternativas.

Um passo além da divulgação de informações nas respostas jurídicas às figuras dos novos mecanismos de negociação de votos, e que não traz os efeitos negativos das alternativas anteriores, é a vinculação entre a alocação da exposição econômica e a atribuição das responsabilidades e dos deveres interna corporis correspondentes ao exercício de direitos dos acionistas. Os direitos e responsabilidades do acionista, não houvesse novos mecanismos de desacoplamento - com exceção das hipóteses tradicionais de separação desses direitos -, estariam concentrados no mesmo titular e, dessa forma, balanceariam os mecanismos de incentivos e responsabilidades interna corporis.

Nesse sentido, a responsabilização por exercício abusivo do direito de voto, ou exercício de voto em conflito de interesses em relação ao interesse social, ou em situação de benefício particular, poderia vir a ser estendida aos terceiros que suportam a exposição econômica das ações e influenciem a manifestação dos direitos políticos pelo titular formal das ações. Ou seja, não apenas o acionista, do ponto de vista formal, mas também o terceiro a quem foi transferida a exposição econômica decorrente da titularidade das ações seriam conjuntamente responsáveis pela manifestação dos direitos políticos do acionista formal, caso ambos tenham concorrido na formação do sentido dessa manifestação.

Dessa forma, por meio da adequada alocação das responsabilidades e deveres dos envolvidos (acionistas e terceiros), podem-se corrigir possíveis desalinhamentos originados do desacoplamento dos direitos de sócio e poderes de interferência na companhia, sem, contudo, inviabilizar a ocorrência dos novos mecanismos de dissociação dos direitos de acionista.

Fato é que as novas figuras de voto vazio (empty voting) e propriedade oculta (conversível) (hidden (morphable) ownership), acompanhadas da possibilidade de dissociação de direitos decorrentes da condição de sócio e da transferência da propriedade econômica das ações pelos acionistas a terceiros, por meios lícitos e bastante recorrentes nas operações realizadas atualmente em mercado, atingem pressupostos do direito societário, que fundamentam os mecanismos atualmente consolidados de incentivos existentes nas companhias e de alocação do exercício de direitos e das responsabilidades a eles atreladas.

Essa constatação não significa que as novas figuras sejam indesejáveis em si mesmas, mas, pelo contrário, indica a necessidade de o direito societário e o direito do mercado de capitais serem revisitados para que possam tratá-las de forma adequada, sendo as possíveis respostas apresentadas anteriormente uma proposta inicial para essa construção. 
Abrem-se, assim, novas perspectivas para a construção do direito societário, em busca de captar adequadamente a realidade econômica e conferir-lhe o melhor tratamento jurídico. Não se chegou, portanto, ao "fim da história do direito societário", ${ }^{194}$ que tem novos e relevantes desafios a enfrentar.

São Paulo, 23 de março de 2019.

\section{Referências}

AKERLOF, George Arthur. The market for "lemons": quality uncertainty and the market mechanism. The Quarterly Journal of Economics, Oxford, v. 84, n. 3, p. 488-500, August 1970.

ALLEN, Franklin; GALE, Douglas. Financial innovation and risk sharing. Cambridge: MIT, 1994. ALVES, José Carlos Moreira. Da alienação fiduciária em garantia. São Paulo: Saraiva, 1973.

ASCARELLI, Tullio. Appunti di diritto commerciale: società e associazioni commerciali. 3. ed. Roma: Foro Italiano, 1936.

ASCARELLI, Tullio. Corso di diritto commerciale: introduzione e teoria dell'impresa. 3. ed. Milano: Giuffrè, 1962.

ASCARELLI, Tullio. Problemas das sociedades anônimas e direito comparado. São Paulo: Saraiva, 1945.

ASCARELLI, Tullio. Saggi di diritto commerciale. Milano: Giuffrè, 1955.

ASQUINI, Alberto. Profili dell'impresa. Rivista di Diritto Commerciale, Industriale e Marittimo, Milano, v. 41, 1943.

BAGGIO, Filippo; REBECCA, Giuseppe. Il pegno di strumenti finanziari, di azioni e quote. Milano: Giuffrè, 2005.

BAIRD, Douglas G.; RASMUSSEN, Robert K. Antibankruptcy. The Yale Law Journal, New Haven, v. 119, n. 4, p. 648-699, 2010.

BARBI FILHO, Celso. Acordo de acionistas. Belo Horizonte: Livraria Del Rey, 1993.

BARRY, Jordan M.; HATFIELD, John William; KOMINERS, Scott Duke. On derivatives markets and social welfare: a theory of empty voting and hidden ownership. Virginia Law Review, Charlottesville, v. 99, n. 6, p. 1.103-1.167, 2013.

BAYER, Walter. Empfehlen sich besondere Regelungen für börsennotierte und für geschlossene Gesellschaften? Gutachten E zum 67. Deutschen Juristentag Erfurt. München: C. H. Beck, 2008.

\footnotetext{
194 Faz-se referência aos estudos de Hansmann e Kraakman (2000; 2012).
} 
BEBCHUK, Lucian Arye. Why firms adopt antitakeover arrangements. University of Pennsylvania Law Review, Philadelphia, v. 152, n. 2, p. 713-753, 2003.

BEBCHUK, Lucian Arye; COHEN, Alma. The costs of entrenched boards. Journal of Financial Economics, Amsterdam, v. 78, n. 2, p. 409-433, November 2005.

BEBCHUK, Lucian Arye; KRAAKMAN, Reinier; TRIANTIS, George Gregory. Stock pyramids, cross-ownership, and dual class equity: the mechanisms and agency costs of separating control from cash-flow rights. In: MORCK, Rendall. Concentrated corporate ownership. Chicago: University of Chicago Press, 2000. p. 295-318.

BERDOU, Arnaud. Mieux encadrer l'«empty voting». Droit des Sociétés, Paris, n. 11, p. 3, Nov. 2011.

BERLE JR., Adolf Augustus; MEANS, Gardiner Coit. The modern corporation and private property. New York: Macmillan Company, 1936.

BETTI, Emilio. Interpretazione della legge e degli atti giuridici: teoria generale e dogmatica. 2. ed. Milano: Giuffrè, 1971.

BLACK, Bernard S. Equity decoupling and empty voting: the Telus zero-premium share swap. The M\&A Lawyer, Little Falls, v. 1, p. 4-8, Oct. 2012.

BLACK, Bernard S.; KRAAKMAN, Reinier. A self enforcing model of corporate law. Harvard Law Review, Cambridge, v. 109, p. 1.911-1.982, 1996.

BRAV, Alon et al. Hedge fund activism, corporate governance, and firm performance. The Journal of Finance, New York, v. 63, n. 4, p. 1.729-1.775, Aug. 2008.

BRAV, Alon; MATHEWS, Richmond D. Empty voting and the efficiency of corporate governance. Journal of Financial Economics, Amsterdam, v. 99, n. 2, p. 289-307, Feb. 2011.

BRIGGS, Thomas W. Corporate governance and the new hedge fund activism: an empirical analysis. Journal of Corporation Law, Iowa, v. 32, n. 4, p. 681-738, 2007.

BULGARELLI, Waldirio. A Teoria jurídica da empresa: análise jurídica da empresarialidade. São Paulo: Revista dos Tribunais, 1985.

BULGARELLI, Waldirio. Regime jurídico da proteção às minorias nas $S / A$ : de acordo com a reforma da Lei n. 6404/76. Rio de Janeiro: Renovar, 1998.

BUONOCORE, Vincenzo. Le situazioni soggettive dell'azionista. Napoli: Morano, 1960.

BUZAID, Alfredo. Ensaio sobre a alienação fiduciária em garantia: lei n. 4.728, art. 66. São Paulo: Acrefi, 1969.

CARVAlHOSA, Modesto Souza Barros. Acordo de acionistas: homenagem a Celso Barbi Filho. São Paulo: Saraiva, 2011a. 
CARVAlHOSA, Modesto Souza Barros. Comentários à lei de sociedades anônimas. 5. ed. São Paulo: Saraiva, 2011b. v. 2.

CEREZETTI, Sheila Christina Neder. Regulação do mercado de capitais e desenvolvimento. In: SALOMÃO FILHO, Calixto (org.). Regulação e desenvolvimento: novos temas. São Paulo: Malheiros, 2012. p. 190-248.

CHRISTOFFERSEN, Susan E. K.; GÉCZY, Christopher C.; MUSTO, David K.; REED, Adam V. Vote trading and information aggregation. The Journal of Finance, New York, v. 62, n. 6, p. 2.8972.929, 2007.

CLARK, Robert C. Corporate law. 2. ed. New York: Aspen, 1986.

CLERC, Christophe. Prêts de titres et opérations assimilées: la question du vote vide. Revue Trimestrielle de Droit Financier, Paris, n. 5, p. 15-19, 2008.

CLOTTENS, Carl. Empty voting: a European perspective. European Company and Financial Law Review, Berlin, v. 9, n, 4, p. 446-483, 2012.

COASE, Ronald Harry. The nature of the firm. Economica, London, v. 4, n. 16, p. 386-405, 1937.

COHEN, Jonathan. Negative voting: why it destroys shareholder value and a proposal to prevent it. Harvard Journal on Legislation, Cambridge, v. 45, n. 1, p. 237-258, Aug. 2008.

COMPARATO, Fábio Konder. Direito empresarial: estudos e pareceres. São Paulo: Saraiva, 1990. COMPARATO, Fábio Konder. Ensaios e pareceres de direito empresarial. Rio de Janeiro: Forense, 1978.

COMPARATO, Fábio Konder; SALOMÃO FILHO, Calixto. O poder de controle na sociedade anônima. 6. ed. rev. e atual. Rio de Janeiro: Forense, 2014.

CORDEIRO, António Menezes. Manual de direito das sociedades. 2. ed., rev. e actual. Coimbra: Almedina, 2007. v. 2: Das sociedades em especial.

COSTA, Philomeno Joaquim da. Aspectos da sociedade por ações. Revista da Faculdade de Direito da Universidade de São Paulo, São Paulo, v. 72, n. 2, p. 47-85, jan./dez. 1977.

COSTA, Philomeno Joaquim da. Representação: inexistência no Direito Romano: análise atual da matéria: exclusão do núncio e do órgão da pessoa jurídica. Revista dos Tribunais, São Paulo, v. 488, n. 65 , p. $35-48$, jun. 1976 .

COTTINO, Gastone. Le convenzioni di voto nelle società commerciale. Milano: Giuffrè, 1958.

ČULINOVIĆ-HERC, Edita; ZUBOVIĆ, Antonija. Tackling empty voting in the EU: the shareholders' rights directive and the revised transparency directive. Croatian Yearbook of European Law and Policy, Zagreb, v. 11, p. 133-160, 2015. 
DARI-MATTIACCI, Giuseppe; GELDERBLOM, Oscar; JONKER, Joost; PEROTTI, Enrico Camillo. The emergence of the corporate form. The Journal of Law, Economics, and Organization, Oxford, v. 33, n. 2, p. 193-236, May 2017.

DAS, Sanjiv Ranjan; HANOUNA, Paul. Hedging credit: equity liquidity matters. Journal of Financial Intermediation, Amsterdam, v. 18, n. 1, p. 112-123, Jan. 2009.

DE LUCCA, Newton. Da ética geral à ética empresarial. São Paulo: Quartier Latin, 2009.

DE NARDIS, Eugenio Simone; TONELLO, Matteo. Know your shareholders: the use of cashsettled equity derivatives to hide corporate ownership interests. The Conference Board, 2010.

DÍAZ RUIZ, Emilio. Reflexiones sobre la aplicación de la institución del voto vacio (empty voting) en las sociedades de responsabilidad limitada. Madri: Facultad de Ciencias Económicas y Empresariales, oct. 2013.

DONALD, David C. The rise and effects of the indirect holding system: how corporate America ceded its shareholders to intermediaries. Frankfurt am Main: Johann-Wolfgang-Goethe-Univ., Inst. for Law and Finance, 2007.

DUFFIE, Darrell; GÂRLEANU, Nicolae. Risk and valuation of collateralized debt obligations. Financial Analysts Journal, New York, v. 57, n. 1, p. 41-59, 2001.

EASTERBROOK, Frank H.; FISCHEL, Daniel R. The economic structure of corporate law. Cambridge: Harvard University Press, 1996.

EASTERBROOK, Frank H.; FISCHEL, Daniel R. Voting in corporate law. The Journal of Law \& Economics, Chicago, v. 26, n. 2, p. 395-427, Jun. 1983.

EISENBERG, Melvin Aron. The conception that the corporation is a nexus of contracts, and the dual nature of the firm. Journal of Corporate Law, Iowa City, v. 24, n. 4, p. 819-836, Summer 1999.

ESCARRA, Jean; ESCARRA, Édouard; RAULT, Jean. Traité théorique et pratique de droit commercial. Paris: Recueil Sirey, 1955. t. 3.

FERRARA, Francesco; CORSI, Francesco. Gli imprenditore e le società. 9. ed. Milano: Giuffrè, 1994.

FERRARINI, Guido. Prestito titoli e derivati azionari nel governo societario. In: BALZARINI, Paola; CARCANO, Giuseppe; VENTORUZZO, Marco (cur.) La società per azioni oggi. Milano: Giuffrè, 2007. v. 2.

FERREIRA, Waldemar Martins. A elaboração do conceito de emprêsa para extensão do âmbito do direito comercial. Revista Forense, São Paulo, v. 158, p. 35-42, mar./abr. 1955.

FERREIRA, Waldemar Martins. Sociedades commerciaes irregulares. São Paulo: Limitada, 1927.

FERREIRA, Waldemar Martins. Tratado de direito comercial. São Paulo: Saraiva, 1961. v. 4: o estatuto da sociedade por ações. 
FERREIRA, Waldemar Martins. Tratado de sociedades mercantis. Rio de Janeiro: Nacional de Direito. 1958. v. 4: Sociedades anônimas.

FERRI, Giuseppe. l'esercizio del voto nel pegno di azioni. Rivista del Diritto Commerciale e del Diritto Generale delle Obbligazioni, Milano, v. 36, n. 2, 1938.

FLEISCHER, Victor. Regulatory arbitrage. Texas Law Review, Austin, v. 89, n. 2, p. 227-290, Dec. 2010 .

FORGIONI, Paula Andrea. A evolução do direito comercial brasileiro: da mercancia ao mercado. São Paulo: Revista dos Tribunais, 2009.

FORGIONI, Paula Andrea. A unicidade do regramento jurídico das sociedades limitadas e o art. 1.053 do Código Civil: usos e costumes e regência supletiva. In: ADAMEK, Marcelo Vieira von (coord.). Temas de direito societário e empresarial contemporâneos: liber amicorum: Prof. Dr. Erasmo Valladão Azevedo e Novaes França. Malheiros: São Paulo, 2011.

FRANÇA, Erasmo Valladão Azevedo e Novaes. Conflito de interesses nas assembléias de S.A. São Paulo: Malheiros, 1993.

FRANÇA, Erasmo Valladão Azevedo e Novaes. Temas de direito societário, falimentar e teoria da empresa. São Paulo: Malheiros, 2009.

GALGANO, Francesco. Lex mercatoria. 5. ed. Bologna: Il Mulino, 2010.

GEORGAKOPOULOS, Nicholas L. The logic of securities law. Cambridge: Cambridge, July 2017.

GILSON, Ronald J.; WHITEHEAD, Charles K. Deconstructing equity: public ownership, agency costs, and complete capital markets. Columbia Law Review, New York, v. 108, n. 1, p. 231-264, Jan. 2008.

GOLDSCHMIDT, Levin. Universalgeschichte des Handelsrechts. Stuttgart: Ferdinand Enke, 1891.

GOMES, Orlando. Alienação fiduciária em garantia. 3. ed., rev. e ampliada. São Paulo: Revista dos Tribunais, 1972.

GUERREIRO, José Alexandre Tavares. O usufruto de ações ao portador e a posição da companhia emissora. Revista de Direito Mercantil, Industrial, Econômico e Financeiro, São Paulo, v. 19, n. 39, p. 84-90, jul./set. 1980a.

GUERREIRO, José Alexandre Tavares. Sobre a opção de compra de ações. Revista de Direito Mercantil, Industrial, Econômico e Financeiro, São Paulo, v. 19, n. 39, p. 226-229, jul./set. 1980b.

HANSMANN, Henry B. The ownership of enterprise. Cambridge: Harvard University Press, 1996.

HANSMANN, Henry B.; KRAAKMAN, Reinier H. Property, contract, and verification: the numerus clausus problem and the divisibility of rights. The Journal of Legal Studies, Chicago, v. 31, n. 2, p. 373-420, 2002. 
HANSMANN, Henry B.; KRAAKMAN, Reinier H. Reflections on the end of history for corporate law. In: RASHEED, Abdul A.; YOSHIKAWA, Toru. (ed.). The convergence of corporate governance: promise and prospects. London: Palgrave Macmillan, 2012. p. 32-48.

HANSMANN, Henry B.; KRAAKMAN, Reinier H. The end of history for corporate law. Discussion Paper No. 280, Cambridge, 2000.

HANSMANN, Henry B.; KRAAKMAN, Reinier H.; ARMOUR, John; PARGENDLER, Mariana. What is corporate law? In: KRAAKMAN, Reinier et al. The anatomy of corporate law: a comparative and functional approach. Oxford: Oxford University Press, 2004.

HANSMANN, Henry B.; PARGENDLER, Mariana. The evolution of shareholder voting rights: separation of ownership and consumption. The Yale Law Journal, New Haven, v. 123, n. 4, p. 9481013, Jan. 2014.

HAZEN, Thomas Lee. Disparate regulatory schemes for parallel activities: securities regulation, derivatives regulation, gambling, and insurance. Annual Review of Banking and Financial Law, Boston, MA, v. 24, p. 375-441, 2005.

HELLER, Michael A. The tragedy of the anticommons: property in the transition from Marx to Markets. Harvard Law Review, Cambridge, v. 111, n. 3, p. 622-688, Jan. 1998.

HU, Henry T. C. "Empty Creditors" and the crisis: how Goldman's \$7 billion was "not material". The Wall Street Journal, 12 Nov. 2009.

HU, Henry T. C. Behind the corporate hedge: information and limits, new financial products the modern process of financial innovation. Journal of Applied Corporate Finance, New York, v. 9, n. 3, p. 39-52, 1996.

HU, Henry T. C. Disclosure universes and modes of information: banks, innovation, and divergent regulatory quests. Yale Journal on Regulation, Atlanta, GA, v. 31, n. 3, p. 565-666, 2014.

HU, Henry T. C. Financial innovation and governance mechanisms: the evolution of decoupling and transparency. The Business Lawyer, Chicago, v. 70, n. 2, p. 347-406, 2015.

HU, Henry T. C. Swaps, the modern process of financial innovation and the vulnerability of a regulatory paradigm. University of Pennsylvania Law Review, Philadelphia, v. 138, n. 2, p. 333-435, 1989.

HU, Henry T. C.; BLACK, Bernard S. Debt, equity, and hybrid decoupling: governance and systemic risk implications. University of Texas Law, Law and Economics Research Paper, 2008b.

HU, Henry T. C.; BLACK, Bernard S. Empty voting and hidden ownership: taxonomy, implications and reforms. Business Lawyer, Chicago, v. 61. n. 3, p. 1.011-1.070, $2006 \mathrm{~b}$.

HU, Henry T. C.; BLACK, Bernard S. Equity and debt decoupling and empty voting II: importance and extensions. University of Pennsylvania Law Review, Philadelphia, v. 156, n. 3, p. 625-739, Jan. 2008a. 
HU, Henry T. C.; BLACK, Bernard S. Hedge funds, insiders, and the decoupling of economic and voting ownership: empty voting and hidden (morphable) ownership. Journal of Corporate Finance, Hoboken, v. 13, n. 1-2, p. 343-367, Jun. 2007.

HU, Henry T. C.; BLACK, Bernard S. The new vote buying: empty voting and hidden (morphable) ownership. Southern California Law Review, Los Angeles, v. 79, n. 4, p. 811-908, 2006 a.

HU, Henry T. C.; WESTBROOK, Jay Lawrence. Abolition of the corporate duty to creditors. Columbia Law Review, New York, v. 107, n. 6, p. 1.321-1.403, 2007.

HUECK, Alfred; CANARIS, Claus-Wilhelm. Recht der Wertpapiere. München: Vahlen, 1986.

INZITARI, Bruno. Profili del diritto dele obbligazioni. Padova: CEDAM, 2000.

IRTI, Natalino. L'ordine giuridico del mercato. 5. ed. Roma: Laterza, 2004.

JENSEN, Michael C. Eclipse of the public corporation. Harvard Business Review, Boston, v. 67, n. 5, p. 61-74, Sept./Oct. 1989.

JENSEN, Michael C.; MECKLING William H. Theory of the firm: managerial behavior, agency costs and ownership structure. Journal of Financial Economics, Amsterdam, v. 3, n. 4, p. 305-360, 1976.

JOBST, Norbert; SERVIGNY, Arnaud de. An empirical analysis of equity default swaps II: multivariate insights. Mar. 2005.

KAHAN, Marcel; ROCK, Edward B. Hedge funds in corporate governance and corporate control. University of Pennsylvania Law Review, Philadelphia, v. 155, n. 5, p. 1.021-1.093, 2007.

KAHAN, Marcel; ROCK, Edward B. The hanging chads of corporate voting. Georgetown Law Journal, Washington, DC, v. 96, n. 4, p. 1.227-1.282, 2008.

KALAY, Avner; PANT, Shagun. Time varying voting rights and the private benefits of control. Social Science Research Network, Rochester, 2009.

KARMEL, Roberta S. Voting power without responsibility or risk: how should proxy reform address the decoupling of economic and voting rights? Villanova Law Review, Villanova, v. 55, n. 1, p. 93-123, 2010.

KNIEHASE, Martin R. Derivate auf eigene Aktien. Berlin: Duncker \& Humblot, 2005.

KUMPAN, Christoph; MITTERMEIER, Martin. Risikoentleerte Stimmrechte - Auswirkungen von Wertpapierdarlehen im Gesellschaftsrecht. Zeitschrift für Wirtschaftsrecht, Köln, v. 30, n. 9, p. 404410, 2009.

LAMY FILHO, Alfredo; PEDREIRA, José Luiz Bulhões (coord.). A Lei das S.A. 2. ed. Rio de Janeiro: Renovar, 1995. v. 1.

LAMY FILHO, Alfredo; PEDREIRA, José Luiz Bulhões (coord.). A Lei das S.A. 2. ed. Rio de Janeiro: Renovar, 1996. v. 2. 
LAMY FILHO, Alfredo; PEDREIRA, José Luiz Bulhões (coord.). Direito das companhias, Rio de Janeiro: Forense, 2009. v. 1.

LE NABASQUE, Hervé. L'empty voting est à l'ordre du jour. Revue de Droit Bancaire et Financier, Bruguières, n. 3, Mars 2010.

LEÃES, Luiz Gastão Paes de Barros. A álea normal do contrato e o momento do exercício das opções. Revista de Direito Bancário e do Mercado de Capitais, São Paulo, v. 11, n. 39, p. 101-115, jan./mar. 2008.

LEÃES, Luiz Gastão Paes de Barros. Do direito do acionista ao dividendo. São Paulo: Obelisco, 1969.

LEÃES, Luiz Gastão Paes de Barros. Pareceres. São Paulo: Singular, 2004a. v. 1.

LEÃES, Luiz Gastão Paes de Barros. Pareceres. São Paulo: Singular, 2004b. v. 2.

LEGNANI, Simone. I patti parasociali occulti tra opa obbligatoria e tutela dell'investimento. 2012. Tese (Doutorado) - Università Cattolica del Sacro Cuore, Milano, 2012.

LOSS, Louis; SELIGMAN, Joel. Fundamentals of securities regulation. 5. ed. New York: Aspen, 2003.

LOWENFELS, Lewis D.; BROMBERG, Alan R. Securities market manipulations: an examination and analysis of domination and control, frontrunning, and parking. Albany Law Review, New York, v. 55, n. 2, p. 293- 365, 1991.

LU, Carmen X. W. Unpacking wolf packs. The Yale Law Journal, New Haven, v. 125, n. 3, p. $773-$ 783, Jan. 2016.

LUCA, Nicola de. Titolarità vs. legittimazione: a proposito di record date, empty voting e "proprietà nascosta" di azioni. Rivista di Diritto Societario, Torino, v. 2, 312-340, 2010.

MANNE, Henry Girard. Some theoretical aspects of share voting. An essay in honor of Adolf A. Berle. Columbia Law Review, New York, v. 64, n. 8, p. 1.427-1.445, Dec. 1964.

MANNING, Bayless. A concise textbook on legal capital. 2. ed. Mineola, N.Y.: Foundation Press, 1981.

MARCONDES, Sylvio. Problemas de direito mercantil. São Paulo: Max Limonad, 1970.

MARCONDES, Sylvio. Questões de direito mercantil. São Paulo: Saraiva. 1977.

MARTIN, Shaun; PARTNOY, Frank. Encumbered shares. University of Illinois Law Review, Urbana, v. 2005, n. 3, p. 775-814, 2005.

MARTINS-COSTA, Judith Hofmeister. A boa-fé no direito privado: critérios para sua aplicação. São Paulo: Marcial Pons, 2015. 
MEDOVA, Elena A.; SMITH, Robert G. Pricing equity default swaps using structural credit models. Aug. 2004.

MENDONÇA, José Xavier Carvalho de. Tratado de direito commercial brasileiro. 6. ed. Rio de Janeiro: Freitas Bastos, 1959. v. 4.

MENDONÇA, José Xavier Carvalho de. Tratado de direito commercial brasileiro. 6. ed. Rio de Janeiro: Freitas Bastos, 1963. v. 3.

MICHELMAN, Frank I. Ethics, economics and the law of property. Tulsa Law Review, Tulsa, v. 39, n. 3, p. 663-690, 2003.

MIGNOLI, Ariberto. Idee e problemi nell'evoluzione dela "Company" inglese. In: ASCARELLI, Tullio; MIGNOLI, Ariberto. Letture per un corso di diritto commerciale comparato. Milano: Giuffrè, 2007.

MIRANDA, Francisco Cavalcanti Pontes de. Tratado de direito privado. 3. ed. Rio de Janeiro: Borsoi, 1970. t. 1: parte geral: introdução. Pessoas físicas e jurídicas.

MIRANDA, Francisco Cavalcanti Pontes de. Tratado de direito privado. 3. ed. São Paulo: Revista dos Tribunais, 1984. t. 50: parte especial. Direito das obrigações: sociedade por ações.

MITTERMEIER, Martin. Empty Voting: Risikoentleerte Stimmrechtsausübung im Recht der börsennotierten Aktiengesellschaft. Berlin: De Gruyter, 2014.

MUÑOZ PÉREZ, Ana Felícitas. Los derivados financieros equity y el gobierno corporativo de las sociedades. Madrid: Marcial Pons, 2013.

OSTLER, Nicolas Anselm. Stimmrecht ohne Beteiligungsinteresse: Erwerb und Ausübung des Aktienstimmrechts ohne das Vermögensinteresse an der Beteiligung. Frankfurt: Peter Lang, 2010.

PAILLUSSEAU, Jean. La société anonyme: techinique juridique d'organisation de l'enterprise. Paris: Sirey, 1967.

PARTNOY, Frank. Adding derivatives to the corporate law mix. Georgia Law Review, Athens, v. 34, n. 2, p. 599-629, 2000.

PARTNOY, Frank. Financial derivatives and the costs of regulatory arbitrage. Journal of Corporate Law, Iowa, v. 22, n. 2, p. 211-256, 1997.

PEDROL, Antonio. La anónima actual y la sindicación de acciones. Madrid: Derecho Privado, 1969.

PELA, Juliana Krueger. As golden shares no direito societário brasileiro. São Paulo: Quartier Latin, 2012.

PENTEADO, Mauro Bardawil. O penhor de ações no direito brasileiro. São Paulo: Malheiros, 2008. 
PENTEADO, Mauro Rodrigues. Aumento de capital das sociedades anônimas. São Paulo: Saraiva, 1988.

PENTEADO, Mauro Rodrigues. Dissolução e liquidação de sociedades. 2. ed. rev., ampl. e atual. São Paulo: Saraiva, 2000.

REQUIÃO, Rubens. Curso de direito comercial. 2. ed. atualizada e aumentada. São Paulo: Saraiva, 1973.

RIBSTEIN, Larry E.; KOBAYASHI, Bruce Harold. Outsider trading as an incentive device. University of California Davis Law Review, Davis, v. 40, n. 1, p. 21-84, 2006.

RINGE, Wolf-Georg. Empty voting revisited: the Telus saga. Journal of International Banking and Financial Law, London, v. 28, n. 3, p. 154-156, 2013a.

RINGE, Wolf-Georg. Hedge funds and risk-decoupling: the empty voting problem in the European Union. Seattle University Law Review, Seattle, v. 36, n. 2, p. 1.027-1.115, 2013 b.

RINGE, Wolf-Georg. The deconstruction of equity: activist shareholders, decoupled risk and corporate governance. Oxford: Oxford University Press, 2016.

RIPERT, Georges. Aspects juridiques du capitalisme moderne. Paris: Librairie Générale de Droit et de Jurisprudence, 1946.

RIPERT, Georges; ROBLOT, René. Traité élémentaire de droit commercial. 6. ed. Paris: LGDJ Librairie Générale de Droit et de Jurisprudence, 1968.

ROBERT, Bruno. A dissociação entre o exercício do direito de voto e o estado de sócio no mercado de capitais contemporâneo: o caso do empréstimo de ações. In: FRANÇA, Erasmo Valladão Azevedo e Novaes (coord.). Direito Societário Contemporâneo II. São Paulo: Malheiros, 2015. p. 45-70.

ROBERT, Bruno. As assembleias das S/A: exercício do direito de voto, pedidos públicos de procuração e participação a distância. São Paulo: Singular, 2016.

ROBERT, Bruno. Dividendo mínimo obrigatório nas S/A: apuração, declaração e pagamento. São Paulo: Quartier Latin, 2011.

SALOMÃO FILHO, Calixto. O novo direito societário. 4. ed., rev. e ampl. São Paulo: Malheiros, 2011.

SALOMÃO FILHO, Calixto. Sociedades comerciais: contratualismo, institucionalismo e análise estruturalista do interesse social. In: SALOMÃO FILHO, Calixto. Teoria crítico-estruturalista do direito comercial. São Paulo: Marcial Pons, 2015. p. 153-177.

SCHAPIRO, Mary L. The derivatives revolution and the world financial system. In: Annual Symposium for the Foundation for Research in International Banking and Finance, 8, 1993, Lugano. 
Remarks at the Eighth Annual Symposium for the Foundation for Research in International Banking and Finance. Washington, D.C.: United States Securities And Exchange Commission, Oct. 1993.

SCIMEMI, Ettore. La vendita del voto nelle socità per azioni. Milano: Giuffrè, 2003.

SENA, Giuseppe. Il voto nella assemblea dela società per azioni. Milano: Giuffrè, 1961.

SHLEIFER, Andrei; VISHNY, Robert Ward. The limits of arbitrage. The Journal of Finance, Malden, v. 52, n. 1, p. 35-55, 1997.

SILVA, Oscar Joseph de Plácido e. Noções práticas de direito comercial. 12. ed. Rio de Janeiro: Forense, 1965. v. 1.

SKEEL, David A.; PARTNOY, Frank. The promise and perils of credit derivatives. University of Cincinnati Law Review, Cincinnati, v. 75, n. 3, p. 1.019-1.052, 2007.

SOPRANO, Enrico. Elementi di diritto commerciale. Torino: Fratelli Bocca, 1923.

SOUZA JÚNIOR, Francisco Satiro. Regime jurídico das opções negociadas em bolsas de valores. 2002. Tese (Doutorado) - Faculdade de Direito, Universidade de São Paulo, São Paulo, 2002.

STIGLER, George Joseph. Law or economics? The Journal of Law and Economics, Chicago, v. 35, n. 2, p. 455-468, Oct. 1992.

SWITZER, Lorne; SHAN, Qianyin. Position growth rate interactions between exchange-traded derivatives and OTC derivatives. Revue Gestion 2000, Paris, v. 31, n. 4, p. 35-63, 2014.

SZTAJN, Rachel. Contrato de sociedade e formas societárias. São Paulo: Saraiva, 1989.

SZTAJN, Rachel. Direito de recesso. 1982. Tese (Doutorado) - Faculdade de Direito, Universidade de São Paulo, São Paulo, 1982.

SZTAJN, Rachel. Direito societário e informação. In: CASTRO, Rodrigo Rocha Monteiro de; GUERREIRO, Carolina Dias Tavares; WARDE JÚNIOR, Walfrido Jorge. (coord.). Direito empresarial e outros estudos de direito em homenagem ao professor José Alexandre Tavares Guerreiro. São Paulo: Quartier Latin, 2013. p. 215-236.

SZTAJN, Rachel. Law and economics. In: ZYLBERSZTAJN, Décio; SZTAJN, Rachel. (org.) Direito \& Economia: análise econômica do direito e das organizações. Rio de Janeiro: Elsevier, 2005. p. 74-83.

SZTAJN, Rachel. Sobre a natureza jurídica das opções negociadas em bolsas. Revista de Direito Mercantil, Industrial, Econômico e Financeiro, São Paulo, v. 105, p. 53-69, 1997.

SZTAJN, Rachel. Teoria jurídica da empresa: atividade empresária e mercados. São Paulo: Atlas, 2004.

TAUTGES, Marco. Empty voting und hidden (morphable) ownership: Die Entkopplung des Stimmrechts des Aktionärs einer börsennotierten Aktiengesellschaft von der wirtschaftlichen Bettrofenheit. Berlin: Duncker \& Humblot, 2016. 
TEIXEIRA, Egberto Lacerda; GUERREIRO, José Alexandre Tavares. Das sociedades anônimas no direito brasileiro. São Paulo: J. Bushatsky, 1979. v. 1.

THOMPSON, Robert B. The limits of hedge fund activism. Berkley, 2006.

VALVERDE, Trajano de Miranda. Sociedade por ações: comentários ao Decreto-lei n. 2.627, de 26 de setembro de 1940. Rio de Janeiro: Forense, 1941. v. 1.

VIGREUX, Pierre Benjamin. Les droits des actionnaires dans les sociétés anonymes: théorie et réalité. Paris: Pichon et R. Durand-Auzias, 1953.

VIVANTE, Cesare. Gli azionisti fiduciari (prestanomi) nelle assemblee delle società per azioni. Rivista di Diritto Commerciale, Industriale e Marittimo, Milano, v. 1, 1903.

VIVANTE, Cesare. Istituzione di diritto commerciale. 22. ed. Milano: Ulrico Hoepli, 1922.

VIVANTE, Cesare. Tratatto di diritto commerciale. Milano: Francesco Vallardi, 1923. v. 2: Le società commerciali.

WALD, Arnoldo. Do Regime jurídico do usufruto de cotas de sociedade de responsabilidade limitada e de ações de sociedades anônimas. Revista de Direito Mercantil, Industrial, Econômico e Financeiro, São Paulo, v. 29, n. 77, p. 5-14, jan./mar. 1990.

WIEDEMANN, Herbert. Die Übertragung und Vererbung von Mitgliedschaftsrechten bei Handelsgesellschaften. München: C. H. Beck, 1965.

WIEDEMANN, Herbert. Gesellschaftsrecht. München: C. H. Beck, 2004. v. 2: Recht der Personengesellschaften.

WU, Liuren; CARR, Peter. Stock options and credit default swaps: a joint framework for valuation and estimation. Journal of Financial Econometrics, Cary, v. 8, n. 4, p. 409-449, 2009.

ZANONI, Andrea. Hedge funds' empty voting in mergers and acquisitions: a fiduciary duties perspective. Global Jurist, Berlin, v. 9, n. 4, artigo 4, Oct. 2009.

ZETZSCHE, Dirk Andreas. Challenging wolf packs: thoughts on efficient enforcement of shareholder transparency rules, Jul. 2009. 
